\title{
Differential gene expression in cisplatin-resistant and -sensitive testicular germ cell tumor cell lines
}

\author{
Jan Roška ${ }^{1}$, Lenka Wachsmannová ${ }^{1}$, Lenka Hurbanová ${ }^{1}$, Zuzana Šestáková ${ }^{1}$, \\ Thomas Mueller ${ }^{2}$, Dana Jurkovičováa, ${ }^{1, *}$ and Miroslav Chovanec ${ }^{1, *}$ \\ ${ }^{1}$ Department of Genetics, Cancer Research Institute, Biomedical Research Center, Slovak Academy of Sciences, Bratislava, \\ Slovak Republic \\ ${ }^{2}$ University Clinic for Internal Medicine IV, Hematology/Oncology, Medical Faculty of Martin Luther University Halle-Wittenberg, \\ Halle (Saale), Germany \\ * Co-senior authors
}

Correspondence to: Miroslav Chovanec, email: miroslav.chovanec@savba.sk Keywords: gene expression array; cisplatin; testicular germ cell tumors; prognostic biomarkers; pluripotency factors Received: November 02, $2020 \quad$ Accepted: November 30, $2020 \quad$ Published: December 22, 2020

Copyright: @ 2020 Roška et al. This is an open access article distributed under the terms of the Creative Commons Attribution License (CC BY 3.0), which permits unrestricted use, distribution, and reproduction in any medium, provided the original author and source are credited.

\section{ABSTRACT}

Testicular germ cell tumors (TGCTs) represent a well curable malignity due to their exceptional response to cisplatin (CDDP). Despite remarkable treatment results, approximately $5 \%$ of TGCT patients develop CDDP resistance and die. Exceptional curability makes TGCTs a highly valuable model system for studying the molecular mechanisms of CDDP sensitivity. Our study was aimed at revealing difference in gene expression between the CDDP-resistant and -sensitive TGCT cell lines, and hence at identifying candidate genes that could serve as potential biomarkers of CDDP response. Using gene expression array, we identified 281 genes that are differentially expressed in CDDP-resistant compared to -sensitive TGCT cell lines. The expression of 25 genes with the highest fold change was validated by RT-qPCR. Of them, DNMT3L, GAL, IGFBP2, IGFBP7, L1TD1, NANOG, NTF3, POU5F1, SOX2, WNT6, ZFP42, ID2, PCP4, SLC4OA1 and TRIB3, displayed comparable expression change in gene expression array and RT-qPCR, when all CDDP-resistant TGCT cell lines were pairwise combined with all -sensitive ones. Products of the identified genes are pluripotency factors, or are involved in processes, such as cell metabolism, proliferation or migration. We propose that, after clinical validation, these genes could serve as prognostic biomarkers for early detection of CDDP response in TGCT patients.

\section{INTRODUCTION}

Testicular germ cell tumors (TGCTs) are the most common solid malignity in men with an ever-increasing incidence. Its highest incidence occurs in young men, with an average age of diagnosis of 36 years [1-3]. TGCTs are characterized as the most sensitive malignity to cisplatin (CDDP)-based chemotherapy, making them a very valuable model system for studying the molecular mechanisms underlying CDDP response [4]. Up to $80 \%$ of patients, even in advanced metastatic stage, can be cured with standard first-line CDDP-based chemotherapy. However, about $20 \%$ of patients relapse as a consequence of an inadequate/aberrant response to chemotherapy. The relapsed patients may be cured by salvage chemotherapy.
Despite excellent treatment outcome, approximately 5\% of patients do not respond even to salvage chemotherapy and die due to an adverse treatment response or develop chemoresistance [5-7].

In terms of classification, TGCTs are a heterogeneous group of malignity mainly due to pluripotent properties of the testicular germ cells, whom they originate from [8]. They are derived from abnormally differentiated testicular germ cells which have acquired susceptible genetic changes. During childhood and adolescence, they occur in the precursor stage referred to as germ cell neoplasia in situ of the testis, after which they change to invasive TGCTs [9]. Histologically, TGCTs are classified into two main subgroups, seminomas (SEs) and non-seminomas (NSEs) [10]. SEs account for $55 \%$ of 
TGCTs, are homogenous, and less aggressive. In contrast, NSEs are heterogeneous, contain multiple histological components and show higher aggressiveness. They exhibit embryonic and extra-embryonic differentiation patterns with different phenotypes, embryonal carcinoma (EC), choriocarcinoma (CC), yolk sac tumor (YST) and teratoma (TE) (reviewed in [8, 11-13]).

There are multiple mechanisms contributing to cellular response to CDDP, such as transport systems, interactions of the drug with various intracellular components, DNA damage response (DDR) and repair, cell cycle, senescence, and apoptosis [14]. Since the primary pharmacological target of CDDP is DNA molecule, cytotoxicity of this agent is mainly manifested through induction of DNA damage $[15,16]$. Therefore, correlation between the CDDP sensitivity and expression level of the DDR and repair factors, particularly those involved in nucleotide excision repair (NER), has attracted research attention. Indeed, up-regulation of the NER proteins in various tumor types has repeatedly been associated with a worse prognosis of patients, with decreased NER levels leading to an improved response to CDDP-based chemotherapy and patients' survival [17-21]. In TGCTs, however, data are far from being consistent [22-27], and are still awaiting in-depth consolidation.

Currently, most commonly used TGCT markers are serum levels of $\alpha$-fetoprotein (AFP), $\beta$-subunit of the human chorionic gonadotropin, and lactate dehydrogenase. They are usually used at the stage of diagnosis [28]. In addition, a prognostic factor-based staging system for metastatic TGCTs, established by the International Germ Cell Cancer Cooperative Group (IGCCCG), considers pre-chemotherapy levels of these serum markers as independent prognostic variable alongside with histological type of primary tumor, primary tumor location, and the presence of non-pulmonary visceral metastases, to categorize patients to good, intermediate, or poor prognosis group [29]. However, IGCCCG criteria are not adequate to predict patient outcome precisely, and significant variability exists in the prognosis of patients within the same IGCCCG risk group. Therefore, reliable predictive markers are urgently needed to identify poor prognosis TGCT patients (refractory or those with high risk for relapse) most likely to be disadvantaged from standard first-line CDDP-based chemotherapy and, instead, allowing their early management through more aggressive or experimental therapy.

As multiple factors are involved in CDDP response, high-throughput methods represent a very powerful tool contributing to their discovery. In addition, availability of experimental in vitro models displaying a broad spectrum of CDDP response further extends toolbox required for detailed understanding of processes underlying CDDP toxicity. In case of TGCTs, such cell lines (covering all known histological sub-types) had been established over the years and, in combination with genome- and proteome- wide methods, already contributed to revealing of numerous CDDP response factors [30-32]. Nevertheless, huge gaps in our understanding of CDDP response still exist, and therefore the present study was aimed to potentially increase the total number of the CDDP response factors through the gene expression profiling in the unique sets of CDDP-resistant and -sensitive TGCT cell lines.

\section{RESULTS}

\section{Gene expression profiles in TGCT cell lines}

TGCT cell lines of different origin and histological type displaying a diverse level of CDDP sensitivity were used (Table 1). Cell lines selection was based on the mean $50 \%$ and $90 \%$ inhibitory CDDP concentrations ( $\mathrm{IC}_{50}$ and $\mathrm{IC}_{90}$ values, respectively) demonstrated in our previous studies $[33,34]$, as well as on the $\mathrm{IC}_{50}$ value examined in the present study (Table 1 and Figure 1). Although there seems to be discrepancy between the $\mathrm{IC}_{50}$ values when study by Schaffrath and co-workers [33] is compared to our, a plausible explanation lies in different CDDP treatment conditions and methods used to determine CDDP cytotoxicity: while the previous study used $96 \mathrm{hr}$ CDDP treatment and the sulforhodamin-Bbased assay, we treated TGCT cell lines with CDDP for $24 \mathrm{hr}$ and determined cytotoxicity using the tetrazolium salt (3-(4,5-dimethylthiazol-2-yl)-2,5-diphenyltetrazolium bromide; MTT)-based assay (see section Materials and Methods). Importantly, and in accordance to previous findings, H12.1D [34], 1411HP [35] and 1777NRpmet [36] (collectively referred to as CDDP-resistant) TGCT cell lines are clearly more resistant to CDDP than H12.1 [37], 2102EP [38-41] and NTERA-2 [42-44] (collectively referred to as CDDP-sensitive) cell lines (Table 1).

With the exception of NTERA-2, detailed information on TGCT cell lines (such as original tumor, xenograft tumor etc.) used in this study was provided in our previous study [34]. Cell lines, H12.1, 2102EP and $1411 \mathrm{HP}$, can grow as subcutaneous xenograft tumors in nude mice in accordance to the original descriptions. Furthermore, H12.1 tumors respond to CDDP therapy with regressions, whereas $1411 \mathrm{HP}$ progresses and displays only some degree of growth retardation [45]. 2102EP tumors are even more sensitive than H12.1 tumors and show partly complete regression since these cells can not differentiate and the tumor only contains EC cells, whereas H12.1 cells can differentiate and the tumors are typically composed of EC with YST, CC and TE differentiation representing a typical NSE (our unpublished data). The 1777NRpmet cell line was derived from a retroperitoneal metastasis and classified histologically as EC [36], but does not grow well as xenograft tumor in our experiments (unpublished data). This is likely due to differentiation in more somatic lineages similar to H12.1D, which, however, was in vitro 
Table 1: Characterization of TGCT cell lines used in this study

\begin{tabular}{|c|c|c|c|c|c|c|}
\hline Cell line & Histological type & $\begin{array}{c}\mathrm{CDDP} \\
\text { response }\end{array}$ & $\mathrm{IC}_{50}(\mu \mathrm{M})$ & $\mathrm{IC}_{90}(\mu \mathrm{M})$ & $\mathrm{IC}_{50}(\mu \mathrm{M})^{\mathrm{a}}$ & Reference \\
\hline H12.1 & Established from primary TGCT, displaying morphology of EC & Sensitive & $0.5 \pm 0.11$ & 3 & $6.87 \pm 2.43$ & [37] \\
\hline 2102EP & $\begin{array}{l}\text { Derived from primary tumour classified as TE with YST, with } \\
\text { cells also resembling EC }\end{array}$ & Sensitive & ND & 3 & $5.78 \pm 1.14$ & [38-41] \\
\hline NTERA-2 & Malignant pluripotent EC, clonally derived from Tera- 2 & Sensitive & ND & ND & $5.63 \pm 1.92$ & [42-44] \\
\hline H12.1D & $\mathrm{EC}$, in vitro differentiation medium-induced derivate of $\mathrm{H} 12.1$ & Resistant & $10.45 \pm 3.28$ & ND & $13.34 \pm 8.21$ & {$[34]$} \\
\hline 1411HP & $\begin{array}{l}\text { Established from a patient with metastatic testicular cancer, } \\
\text { showing combined EC and YST }\end{array}$ & Resistant & $4.70 \pm 0.44$ & 10 & $34.93 \pm 1.04$ & [35] \\
\hline 1777NRpmet & $\begin{array}{l}\text { Derived from a retroperitoneal lymph node metastasis showing } \\
\text { differentiated EC with immature TE }\end{array}$ & Resistant & $1.64 \pm 0.74$ & 16 & $11.11 \pm 0.23$ & [36] \\
\hline
\end{tabular}

ND: not determined in quoted reference, TGCT: testicular germ cell tumour, EC: embryonal carcinoma, TE: teratoma, YST: yolk sac tumour. a this study.

differentiated from H12.1 and does not grow as xenograft tumor. Both cell lines show a lack of expression of the embryonal transcription factor OCT4 [34]. In contrast, 1411HP tumors, also lacking OCT4 expression, show differentiation towards extra-embryonal YST [46]. The differentiation aspect is further described in the discussion section.

To disclose the genes that are differentially expressed in CDDP-resistant TGCT cell lines compared with -sensitive ones, various pairwise combinations of cell lines were examined. Since H12.1 and H12.1D TGCT cell lines represent an authentic isogenic pair, a priority was given to data acquired for this particular pairwise combination, even though the H12.D cell line was not directly made to be resistant to CDDP. Nevertheless, a mechanism of CDDP resistance in this cell line, achieved by cultivation in differentiation-inducing medium leading to the loss of POU5F1 expression [34], parallels at the molecular level the one induced directly by CDDP treatment, as demonstrated by the fact that CDDP induces resistance to itself by triggering a differentiation response via decrease in the expression of POU5F1 in pluripotent germ cell tumor (GCT) cells [47]. Other pairs combine non-isogenic cell lines, but data obtained for them can also be valuable, potentially addressing other aspects of TGCT biology related to CDDP response. In line with this statement, a huge overlap in differentially expressed genes between isogenic and non-isogenic pairwise combinations was obtained. In addition, metastatic origin and chemotherapy resistant phenotype of $1411 \mathrm{HP}$ and 1777NRpmet cell lines (Table 1) allowed revealing the genes related to acquired mechanism of CDDP resistance and metastatic phenotype. Finally, analysis comparing all CDDP-resistant TGCT cell lines with all -sensitive ones reflects a histological heterogeneity of the disease that is represented by a prevalent number of mixed tumors.

First, we profiled gene expression in CDDP-resistant (H12.1D, 1411HP and 1777NRpmet) and -sensitive (H12.1) TGCT cell lines to identify differentially expressed genes between the H12.1D vs H12.1, 1411HP vs H12.1, and 1777NRpmet vs H12.1 pairwise cell line combinations. After visualization of microarray signal, differential gene expression was compared. Differences in gene expression (represented as the mean fold change; FC) in CDDP-resistant vs -sensitive TGCT cell lines were considered to be significant, when adjusted $p$ value was $<0.05$. When compared H12.1D with H12.1, statistically significant difference in expression of 2,226 genes was found. Of them, 1,158 genes were down-regulated and 1,068 up-regulated (Figure 2A and Supplementary Table 1). When 1411HP cell line was compared with H12.1, expression of 908 genes was significantly changed, with 636 genes being down-regulated and 272 genes being up-regulated (Figure 2B and Supplementary Table 2). Finally, 1777NRpmet vs H12.1 comparison brought statistical difference in expression of 839 genes, of which 252 and 587 were up- and down-regulated, respectively (Figure 2C and Supplementary Table 3).

\section{Validation of expression of candidate genes}

Parameters for mean $\log \mathrm{FC}>2.0$ and $<0.5$ for up- and down-regulated expression change were further introduced respectively, to narrow the gene data set with $p<0.05$. This set-up disclosed 760 up- and 773 downregulated genes for H12.1D (Supplementary Table 4), 187 up- and 486 down-regulated genes for 1411HP (Supplementary Table 5), and 183 up- and 451 downregulated genes for 1777NRpmet (Supplementary Table 6), when compared with H12.1. After overlapping the obtained data sets, 281 genes displayed significant differential expression in all CDDP-resistant TGCT cell lines when compared with H12.1 -sensitive cell line (Figure 2D and Supplementary Table 7). Of them, 275 genes were comparably down- or up-regulated, while the remaining 6 genes (MAGEL2, LYPD1, NDN, ENPP4, $P R K C D B P$ and TM7SF2) displayed up-regulation in H12.1D, but down-regulation in both $1411 \mathrm{HP}$ and 1777NRpmet (Table 2). Figure 3 shows expression profiles of down- and up-regulated genes with $\log 2-\mathrm{FC}$ with the mean FC $>2.0$ vs CDDP-sensitive H12.1 TGCT cell line.

Datasets shown in Supplementary Tables 4, 5 and 6 were used to select candidate genes for validation by 
Table 2: List of genes that displayed statistically significant up-regulation in primary tumourderived (H12.1D), but down-regulation in metastasis-derived (1411HP and 1777NRpmet), CDDPresistant TGCT cell lines compared to -sensitive H12.1

\begin{tabular}{l}
\hline Gene (aliases) \\
MAGEL2 (PWLS, nM15, \\
NDNL1, SHFYNG)
\end{tabular}

LYPD1 (PHTS, LYPDC1)

NDN (PWCR, HsT16328)

ENPP4 (NPP4)

PRKCDBP (SRBC, HSRBC, CAVIN3, cavin-3)

TM7SF2 (ANG1, C14SR, DHCR14A, NET47)

\section{Molecular/biological function of the protein}

MAGE family member L2

Prader-Willi syndrome (PWS) is manifested by neonatal hypotonia, developmental delay and childhood-onset obesity. Necdin (NDN), a gene involved in the terminal differentiation of neurons, has been implicated as one of the genes responsible for the etiology of PWS. The MAGEL2 gene is structurally similar to NDN, is localized to the PWS chromosomal region and paternally imprinted, and therefore it has a possible role in PWS.

LY6/PLAUR domain containing 1

It may function in a new and p53-independent tumour suppressor pathway.

Necdin, MAGE family member

The gene is located in the PWS deletion region. It is an imprinted gene and is expressed exclusively from the paternal allele. The protein encoded by this gene suppresses growth in postmitotic neurons.

Ectonucleotide pyrophosphatase/phosphodiesterase 4

It is a type I extracellular membrane protein on brain vascular endothelium inducing platelet aggregation via the hydrolysis of Ap3A.

Protein kinase $C$ delta-binding protein

The expression of this protein in cultured cell lines is strongly induced by serum starvation. This protein was found to be down-regulated in various cancer cell lines, suggesting its possible tumour suppressor function.

Transmembrane 7 superfamily member 2

The protein is $3 \beta$-hydroxysterol $\delta(14)$-reductase, responsible for the reduction of C14-unsaturated sterols in cholesterol biosynthesis. The TM7SF2 gene expression is controlled by cell sterol levels.

Source: https://www.ncbi.nlm.nih.gov/genome/guide/human/.

RT-qPCR. In total, 25 genes were selected. Criteria for selection of these genes were based on their appearance in at least two out of three mentioned datasets and their as highest expression change as possible. Notably, and expectedly, expression changes of the selected genes detected by RT-qPCR paralleled the ones obtained by gene expression array, although when CDDP-resistant TGCT cell lines $1411 \mathrm{HP}$ and $1777 \mathrm{NRpmet}$ were pairwise compared with two other CDDP-sensitive cell lines, 2102EP and NTERA-2, it slightly differed, depending on CDDP-sensitive cell line they were normalized against. Therefore, we compared expression of the validated genes only for a pairwise combination H12.1D vs H12.1, as H12.1D cell line is a true isogenic derivative of H12.1. To show high degree of similarity and to simplify data interpretation, we divided the validated genes into two groups, 13 genes that were significantly down-regulated in original gene expression array data set (C11orf96, DNMT3L, GAL, IGDCC3, IGFBP2, IGFBP7, L1TD1, NANOG, NTF3, POU5F1, SOX2, WNT6 and ZFP42) and 12 up-regulated genes $(B E X 2, C C N 1, C Y B 5 A, C Y B 5 R 2$, FADS2, ID2, ISG20, PCP4, REC8, SLC40A1, TMSB4X and TRIB3). Supplementary Table 8 lists these genes along with brief molecular and biological characterization of their products.

\section{Up-regulated genes}

When comparing CDDP-resistant TGCTs cell lines with H12.1 -sensitive control, we observed significant upregulation of the TRIB3, ID2, PCP4, CYB5A, CYB5R2 and $S L C 40 A 1$ genes in all CDDP-resistant cell lines. CCN1 was significantly up-regulated in $1411 \mathrm{HP}$ and 1777NRpmet cell lines $(p<0.001)$, but not in H12.1D $(p=0.088)$. ISG20, REC8 and BEX2 did not display statistically significant up-regulation of their expression in any CDDP-resistant cell line compared with H12.1 ( $p=0.823,0.401$ and 0.059 for $1411 \mathrm{HP}, 1777 \mathrm{NRpmet}$ and H12.1D, respectively). FADS2 was significantly upregulated in both $1411 \mathrm{HP}$ and $1777 \mathrm{NRpmet}$ cell lines and showed a trend of down-regulation in H12.1D, as compared with H12.1. This gene was also significantly down-regulated in 1411HP when compared with 2102EP CDDP-sensitive cell line. TMSB $4 X$ was down-regulated in CDDP-resistant H12.1D cell line when pairwise combined with H12.1, even though in 1411HP and 1777NRpmet it 
was up-regulated. Significantly up-regulated expression of ID2, PCP4, TRIB3, SLC40A1 and CYB5R2 was revealed when $1411 \mathrm{HP}$ and $1777 \mathrm{NRpmet}$ CDDP-resistant cell lines were compared with 2102EP. CYB5A was significantly up-regulated in $1777 \mathrm{NRpmet}$ when pairwise combined with 2102EP ( $p=0.014$ ). Neither 1411HP nor $1777 \mathrm{NRpmet}$ displayed any significant change in expression of the TMSB $4 X, B E X 2, C C N 1, R E C 8$ and ISG20 genes when compared with 2102EP. When 1411HP and 1777 NRpmet cell lines were pairwise combined with NTERA-2, significant change of the TRIB3, PCP4, ID2 and $S L C 40 A 1$ gene expression was observed. When analyzed against NTERA-2, $C Y B 5 R 2$ was significantly down-regulated in $1411 \mathrm{HP}(p=0.047)$ and $C Y B 5 A$ was up-regulated in $1777 \mathrm{NRpmet}(p=0.008)$. Neither $1411 \mathrm{HP}$ nor $1777 \mathrm{NR}$ met demonstrated any significant change in expression of the FADS2, REC8, CCN1, BEX2 and TMSB $4 X$ genes when compared with NTERA-2 (Figure 4). Individual statistical significance for all 25 validated genes is illustrated in Table 3 .

\section{Down-regulated genes}

SOX2, NANOG and POU5F1 were all significantly down-regulated in all CDDP-resistant compared with all -sensitive TGCT cell lines. When CDDP-resistant cell lines were compared only with H12.1, significant downregulation of expression was observed for the $L 1 T D 1$, NTF3, IGFBP2, IGFBP7, DNMT3L, ZFP42 and WNT6 genes. In case of $G A L$, only 1777 NRpmet did not show any significant change in its expression level, while both H12.1D and 1411HP showed significantly downregulated $G A L$ gene expression ( $p=0.04$ and $p<0.001$, respectively). Similarly, $1411 \mathrm{HP}$ was the only CDDPresistant TGCT cell line, which did not display change in the expression level of the IGDCC3 gene, while in both H12.1D and 1777NRpmet significant down-regulation of its expression ( $p<0.001$ and $p=0.036$, respectively) was demonstrated. In case of C11orf96, only H12.1D cell line brought its significant down-regulation $(p=0.02)$.

Down-regulation of the NTF3, IGFBP2 and IGFBP7 genes was observed when their expression in two CDDPsensitive TGCT cell lines (2102EP and NTERA-2) was compared with that in all -resistant cell lines, although data for both -resistant cell lines for NTF3 and for 1777NRpmet for $I G F B P 7$, when pairwise combined with $2102 \mathrm{EP}$, were not statistically significant. $G A L$ gene expression was down-regulated in both 1411HP and 1777NRpmet when compared with 2102EP ( $p<0.001)$, and in 1411HP, but not in 1777NRpmet, when compared with NTERA-2 ( $p<0.001$ and $p=0.175$, respectively). Expression of C11orf96 was not significantly changed in $1411 \mathrm{HP}$ and 1777NRpmet when compared with both 2102EP and NTERA-2. DNMT3L expression was significantly down-regulated in both $1411 \mathrm{HP}$ and $1777 \mathrm{NRpmet}$ when compared with $2102 \mathrm{EP}(p<0.001)$, but not if compared with NTERA-2 $(p=0.104)$. WNT6 gene expression was down-regulated in $1411 \mathrm{HP}$ and $1777 \mathrm{NRpmet}$ TGCT cell lines in comparison with 2102EP $(p<0.001)$, but it did not significantly change in neither of them when

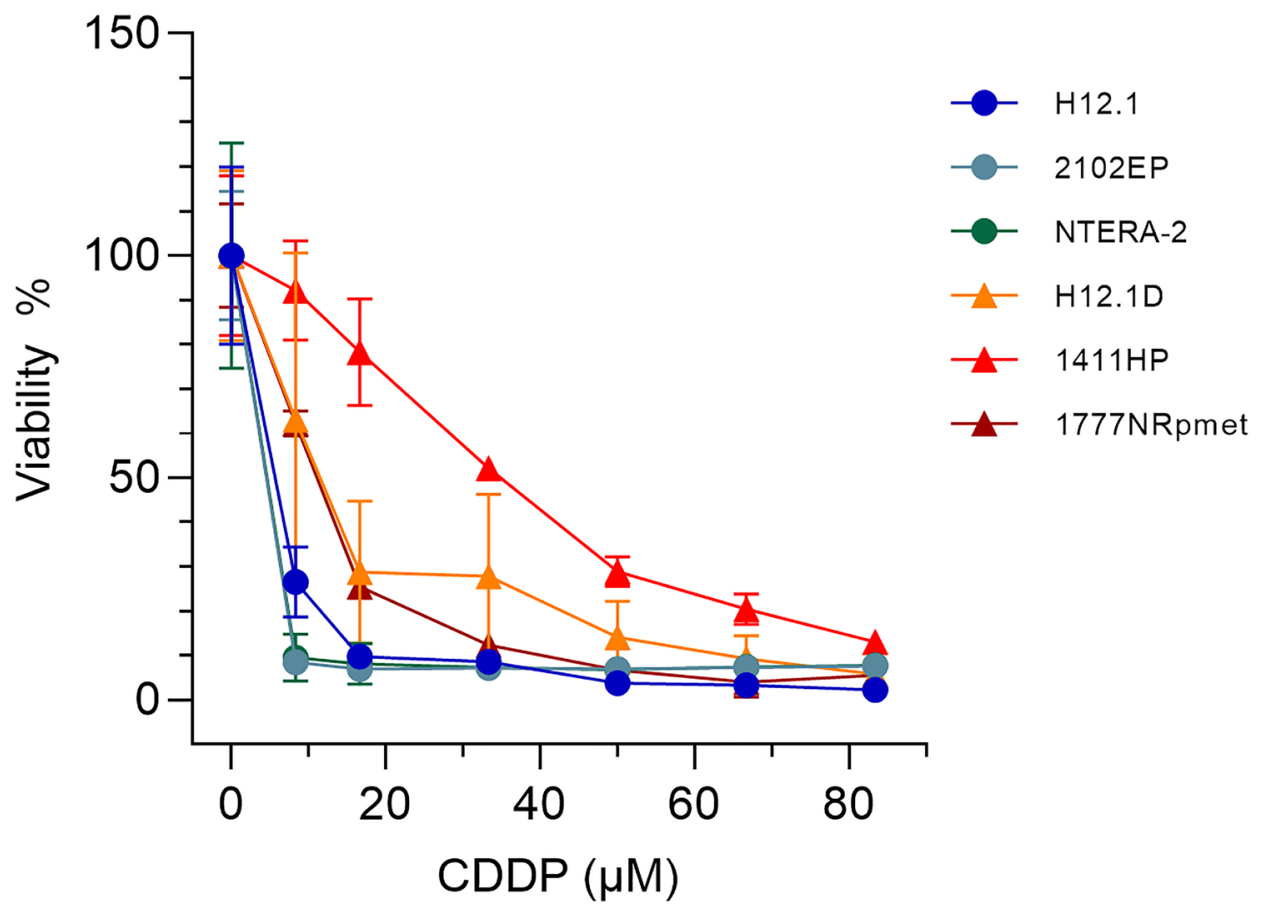

Figure 1: Survival of TGCT cell lines used in this study after CDDP treatment. H12.1, 2102EP, NTERA-2, H12.1D, 1411HP and $1777 \mathrm{NRpmet}$ TGCT cell lines were exposed to the increasing concentrations of CDDP for $24 \mathrm{hr}$ in culture medium and survival was estimated by the MTT test. The obtained curves were used to calculate the $\mathrm{IC}_{50}$ values shown in Table 1. 
Table 3: Statistical analysis of expression for the 25 most differentially expressed genes

\begin{tabular}{|c|c|c|c|c|c|c|c|}
\hline \multirow{3}{*}{ Validated gene } & \multicolumn{7}{|c|}{$p$ value } \\
\hline & \multicolumn{3}{|c|}{ H12.1 } & \multicolumn{2}{|c|}{ 2102EP } & \multicolumn{2}{|c|}{ NTERA-2 } \\
\hline & H12.1D & 1411HP & 1777NRpmet & 1411HP & 1777NRpmet & 1411HP & 1777NRpmet \\
\hline$B E X 2$ & NS & NS & NS & NS & NS & NS & NS \\
\hline CYB5A & 0.0185 & 0.0036 & $<0.001$ & NS & 0.0138 & NS & 0.0079 \\
\hline CYB5R2 & $<0.001$ & $<0.001$ & $<0.001$ & $<0.001$ & $<0.001$ & 0.047 & NS \\
\hline PCP4 & $<0.001$ & $<0.001$ & $<0.001$ & $<0.001$ & $<0.001$ & $<0.001$ & $<0.001$ \\
\hline$I S G 20$ & NS & NS & NS & NS & NS & NS & NS \\
\hline CCN1 & NS & 0.0043 & 0.0013 & $\mathrm{NS}$ & NS & NS & NS \\
\hline$R E C 8$ & NS & NS & NS & NS & NS & NS & NS \\
\hline$T R I B 3$ & 0.0051 & $<0.001$ & $<0.001$ & 0.0016 & 0.0138 & $<0.001$ & $<0.001$ \\
\hline$F A D S 2$ & 0.015 & $<0.001$ & $<0.001$ & 0.035 & $\mathrm{NS}$ & NS & NS \\
\hline ID2 & $<0.001$ & $<0.001$ & $<0.001$ & 0.0310 & 0.0033 & 0.0050 & $<0.001$ \\
\hline$T M S B 4 X$ & $<0.001$ & $<0.001$ & $<0.001$ & NS & NS & NS & NS \\
\hline$S L C 40 A 1$ & $<0.001$ & 0.0021 & $<0.001$ & 0.0095 & $<0.001$ & 0.0042 & $<0.001$ \\
\hline IGFBP 2 & $<0.001$ & $<0.001$ & $<0.001$ & 0.0069 & $<0.001$ & 0.0069 & $<0.001$ \\
\hline$I G F B P 7$ & 0.0012 & $<0.001$ & $<0.001$ & $<0.001$ & NS & $<0.001$ & 0.0162 \\
\hline$L 1 T D 1$ & $<0.001$ & 0.0018 & $<0.001$ & 0.0042 & $<0.001$ & 0.0266 & $<0.001$ \\
\hline NTF3 & $<0.001$ & $<0.001$ & $<0.001$ & NS & NS & NS & 0.0036 \\
\hline$N A N O G$ & $<0.001$ & $<0.001$ & 0.001 & $<0.001$ & $<0.001$ & $<0.001$ & 0.0029 \\
\hline POU5F1 & $<0.001$ & $<0.001$ & $<0.001$ & $<0.001$ & $<0.001$ & $<0.001$ & $<0.001$ \\
\hline $\mathrm{SOX} 2$ & $<0.001$ & 0.0117 & $<0.001$ & 0.0033 & $<0.001$ & 0.0073 & $<0.001$ \\
\hline C11orf96 & 0.0199 & NS & NS & NS & NS & NS & NS \\
\hline DNMT3L & $<0.001$ & $<0.001$ & $<0.001$ & $<0.001$ & $<0.001$ & NS & NS \\
\hline$G A L$ & 0.0039 & $<0.001$ & NS & $<0.001$ & $<0.001$ & $<0.001$ & NS \\
\hline$I G D C C 3$ & $<0.001$ & NS & 0.0362 & NS & 0.0280 & NS & 0.0298 \\
\hline WNT6 & $<0.001$ & 0.0016 & 0.0028 & $<0.001$ & $<0.001$ & NS & NS \\
\hline ZFP42 & $<0.001$ & 0.0011 & $<0.001$ & 0.0026 & $<0.001$ & NS & NS \\
\hline
\end{tabular}

NS: not significant. Boldface gene denotes statistical significance $<0.05$ for all pairwise combinations of CDDP-resistant and -sensitive TGCT cells lines.

compared with NTERA-2 $(p=0.112)$. ZFP42 displayed identical expression change when the same cell lines were pairwise combined. In case of IGDCC3 gene expression, significant down-regulation was observed only in case of 1777NRpmet vs 2102EP and NTERA-2 pairwise combinations ( $p=0.028$ and $p=0.03$, respectively) (Figure 5).

\section{DISCUSSION}

In this work, we compare gene expression profiles between the CDDP-resistant and -sensitive TGCT cell lines using gene expression array. As TGCTs are a wellcurable malignity due to their extraordinary response to CDDP, our primary aim was to reveal the factors that are responsible for their sensitivity to this drug. Furthermore, we wished to disclose potential biomarkers of CDDP response that could be translated into clinical practice and could improve (either alone or in combination with IGCCCG criteria) timely and precise identification of poor prognosis TGCT patients.

We identified 6 genes that showed an opposite regulation in metastasis-derived cell lines, 1411HP and 1777NRpmet (down-regulation), compared to primary tumor-derived H12.1D (up-regulation) cell line, suggesting their regulatory role in metastatic progression of TGCT disease likely via tumor suppressor role. In line with this assumption, LYPD1 has been reported to be a putative tumor suppressor gene because its overexpression in cancer cell lines reduces cell growth likely via induced apoptosis [48]. The PRKCDBP tumor suppressor gene has been shown to be: (i) significantly down-regulated in both breast cancer brain metastases and primary brain cancer 
with brain relapse compared to primary tumors without relapse or bone metastasis [49]; (ii) altered in colorectal cancer [50]; and (iii) contributing to the malignant progression of several tumor types [51-54].

25 genes were selected from gene expression array data set and validated by RT-qPCR. As previously reported, pluripotency factors POU5F1, NANOG and $S O X 2$ are significantly down-regulated in resistant TGCT cell lines and lost during disease progression towards differentiated tissues, TE, YST or CC [55-57]. Notably, down-regulation of POU5F1, NANOG and SOX2 gene expression in CDDP-resistant TGCT cell lines was consistent, and comparable, in both gene expression array and RT-qPCR data sets, confirming previous findings. Accordingly, analysis of POU5F1 on the protein level clearly separates sensitive TGCT cell lines showing high POU 5F 1 expression in resistant TGCT cell lines lacking $P O U 5 F 1$ expression $[34,57]$. A recent study investigating the differentiation-dependent regulation of expression of human endogenous retrovirus $\mathrm{K}$ sequences (HERVK) using these TGCT cell lines confirmed POU5F1 expression pattern and showed high $H E R V K$ expression
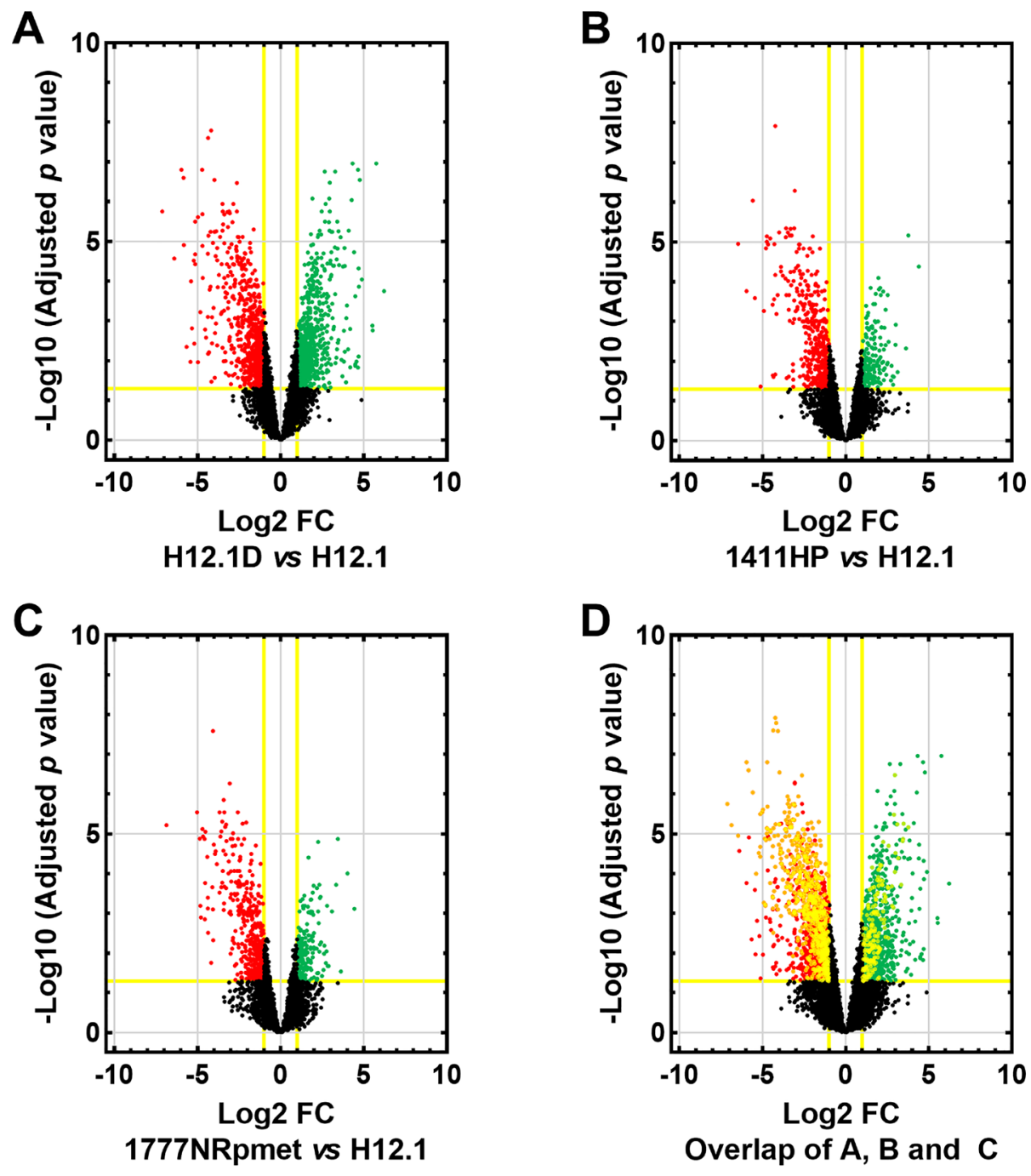

\section{Upregulated Downregulated Overlap NS}

Figure 2: Differentially expressed genes in TGCT cell lines. Differentially expressed genes in CDDP-resistant TGCT cell lines were compared with -sensitive H12.1 cell line. Volcano plot comparisons of mean log2-FC of gene expression between H12.1D and H12.1 (A), 1411HP and H12.1 (B) and 1777NRpmet and H12.1 (C) cell lines. Overlap of all three CDDP-resistant TGCT cell lines vs H12.1 (D). Vertical lines correspond to $>2.0$ up-regulation and $<0.5$ down-regulation. Horizontal line represents a threshold of adjusted $p<0.05$. Green and red points in the volcano plot represent differentially expressed genes that are statistically significant and $>2.0$ up- and $<0.5$ down-regulated. Black points represent gene expression which was not statistically significant, nor showed $>2.0$ up-regulation or $<0.5$ down-regulation. Yellow rims around individual points show genes which had an overlap in all CDDP-resistant TGCT cell lines with 2-FC in expression and an adjusted $p<0.05$. 
in POU5F1-expressing sensitive EC cells (e.g., H12.1), whereas the $P O U 5 F 1$-negative, resistant cells could be further distinguished into cells with extra-embryonic differentiation characteristics towards YST (e.g., 1411HP) showing intermediate level of HERVK, and cells with somatic differentiation characteristics (1777NRpmet and H12.1D) showing low HERVK expression [58]. Therefore, in accordance with pluripotency markers, additional factors found in the present study to be down-regulated in all resistant TGCT cell lines may reflect the loss of the pluripotent state in general (DNMT3L, WNT6 and ZFP42), whereas factors which also differ among resistant cell lines (GAL, IGDCC3,IGFBP2, IGFBP7, L1TD1 and $N T F 3$ ) may further reflect a differentiation towards different lineages. In either case, this is associated with CDDP-resistance.

C11orf96 is an open reading frame, considered as a potential prognostic marker in colorectal cancer [59]. The DNMT3L gene was also classified as a prognostic marker in cervical tumors and GCTs. It is essential for

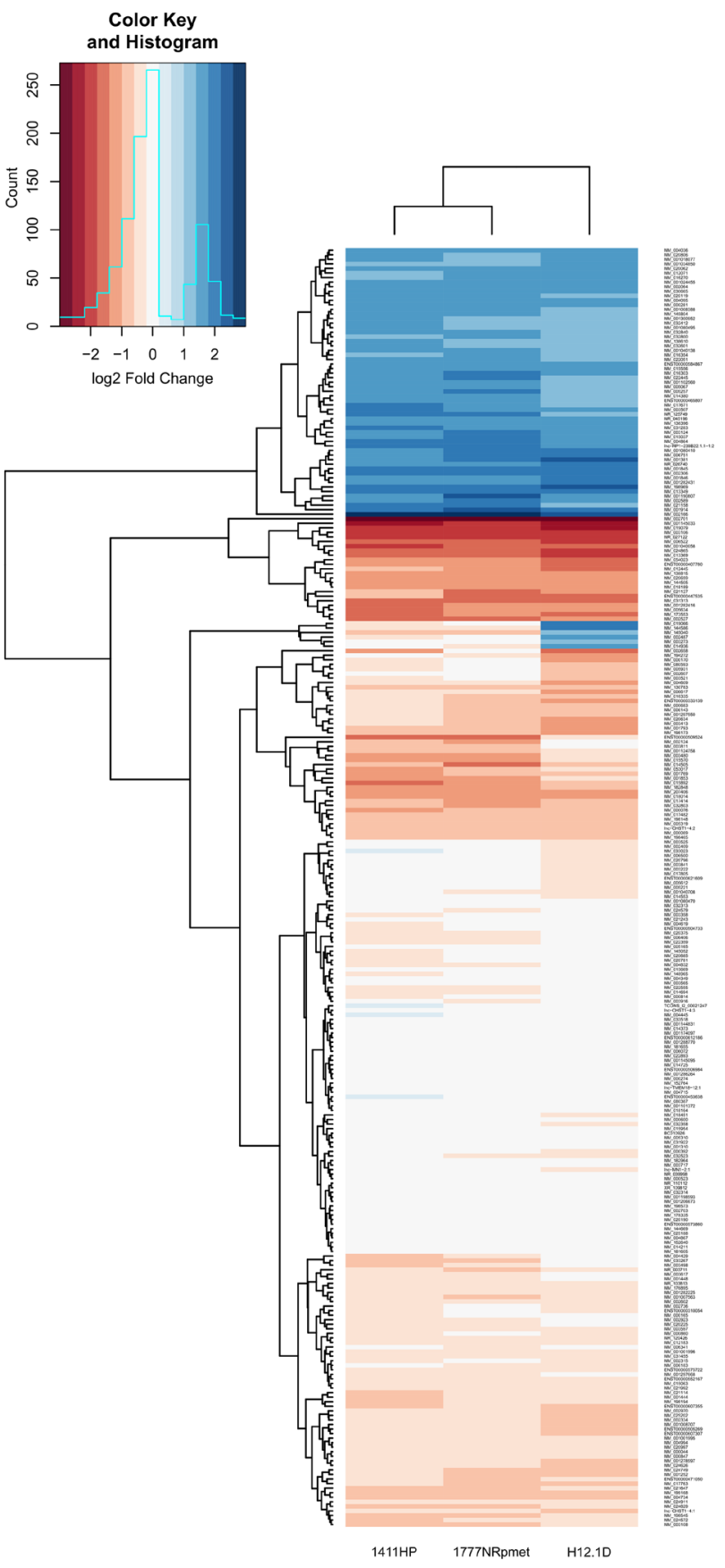

Figure 3: Differentially expressed genes in CDDP-resistant TGCT cell lines. Heatmap illustrates differentially expressed genes with $\log 2$ transformed mean relative expression $>2$ and $p<0.05$ in CDDP-resistant TGCT cell lines in comparison with -sensitive H12.1 TGCT cell line using hierarchical clustering. Red color indicates low relative expression and blue color indicates high relative expression. 
germ cell development, being highly expressed in germ cells and undifferentiated pluripotent stem cells under normal developmental processes, indicating that it is also expressed in germ cell-derived tumors, and is essential for growth of human embryonal cells. Decrease of its expression could be a consequence of hypomethylation of its promoter region, and de-regulation of these processes may lead to CDDP-resistance [60, 61]. IGDCC3 is also potential prognostic marker that is associated with overall survival (OS) and risk of recurrence in breast cancer [62]. Both IGFBP2 and IGFBP7 are members of the IGFBP family, which affect cell proliferation and migration. IGFBP2 inhibits expression of E-cadherin in colorectal cancer [63] and promotes immunosuppression associated with its mesenchymal induction in glioblastoma [64]. IGFBP7 inhibits cell proliferation and cell cycle progression [65]. Higher expression of the IGFBP7 gene in cholangiocarcinoma was associated with better OS [66]. Low IGFBP7 expression is a feature of leukemic stem cells associated with reduced chemotherapy sensitivity [67], suggesting that its expression levels can be considered as a prognostic marker of chemoresistance. L1TD1 is highly expressed gene in pluripotent cells and is important for maintaining the pluripotent state. It has been shown to be controlled by POU5F1, NANOG and SOX2 $[68,69]$, an observation indirectly paralleled by our data. Hence, it seems that L1TD1 might represent marker for phenotyping and monitoring of TGCT progression. WNT6
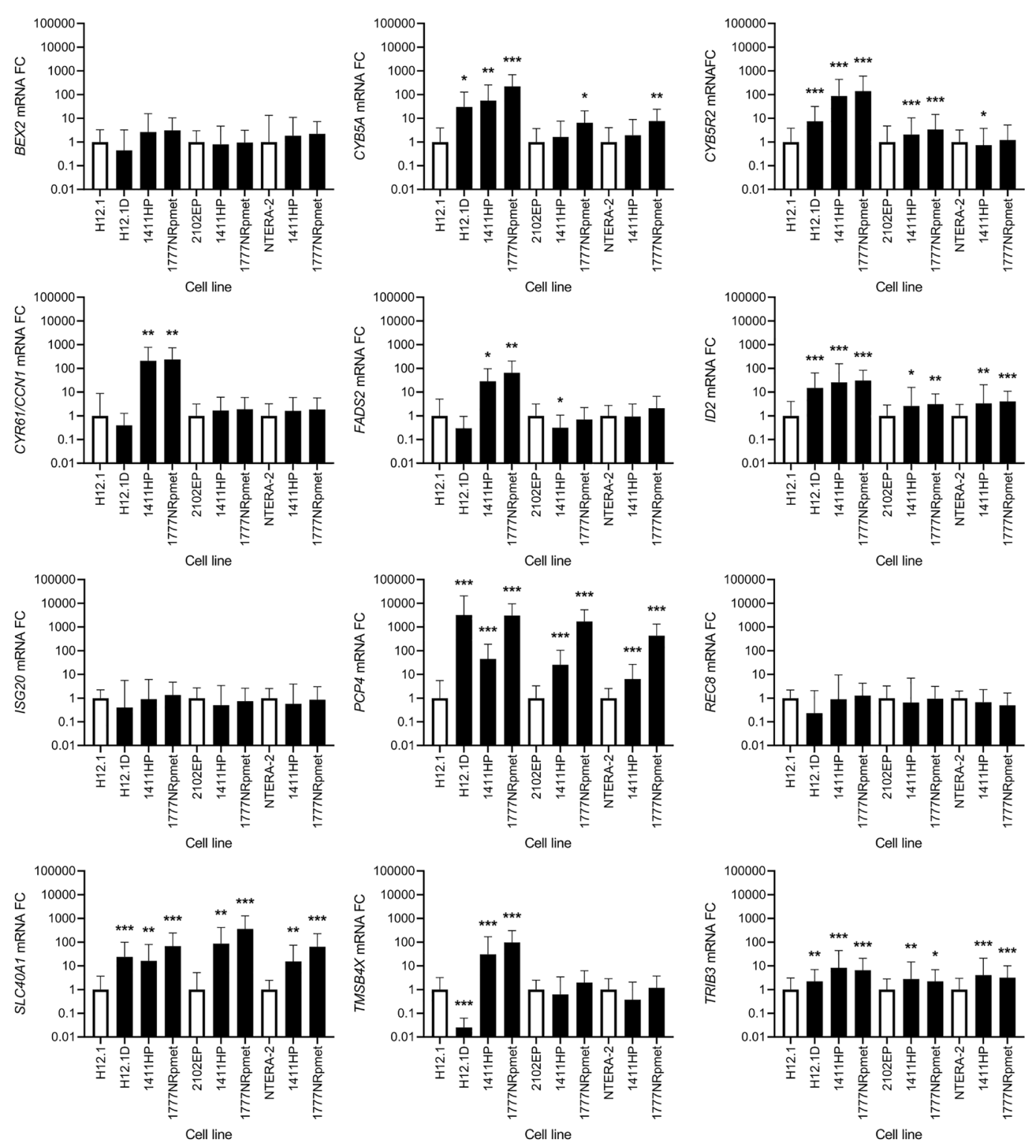

Figure 4: Expression change of 12 candidate genes that were originally identified as up-regulated using gene expression array. CDDP-resistant (H12.1D, 1411HP and 1777NRpmet) and -sensitive (H12.1, 2102EP and NTERA-2) TGCT cell lines are represented as black and white bars, respectively. Error bars represent upper and lower limits of expression of three technical and three biological replicates. ${ }^{*} p \leq 0.05,{ }^{* *} p \leq 0.01,{ }^{* * *} p \leq 0.001$. 
promotes chemoresistance in various cancer cells, as it is up-regulated by chemotherapeutics, thereby enhancing tumor resistance, aggressiveness and progression [70, 71, 72]. Along with SOX2, POU5F1, NANOG, SSEA3 and SSEA-4, ZFP42 is an embryonic marker [73]. NOTCH3 amplification leads to increased expression of genes associated with embryonic stem cell development (NANOG, POU5F1 and ZFP42), ultimately leading to chemoresistance development [74]. Our results suggest that decreased expression of ZFP42 in CDDP-resistant TGCT cell lines in comparison to two CDDP-sensitive cell lines might parallel an L1TD1 situation, considering that $S O X 2, N A N O G$ and POU5F1 expression was also significantly down-regulated, indicating that effect of NOTCH3 on these embryonic markers is deregulated in CDDP-resistant TGCT cell lines.

We found no significant difference in the level of $\mathrm{BEX} 2$, a protein that promotes proliferation in colorectal cancer [75] and regulates cell proliferation and migration, invasion and apoptosis in malignant glioma [76, 77]. Obviously, it does not have a similar effect in GCTs, as demonstrated herein. We found increased expression of the $C Y B 5 A$ and $C Y B 5 R 2$ genes in all CDDP-resistant TGCT cell lines when compared to H12.1 -sensitive cell
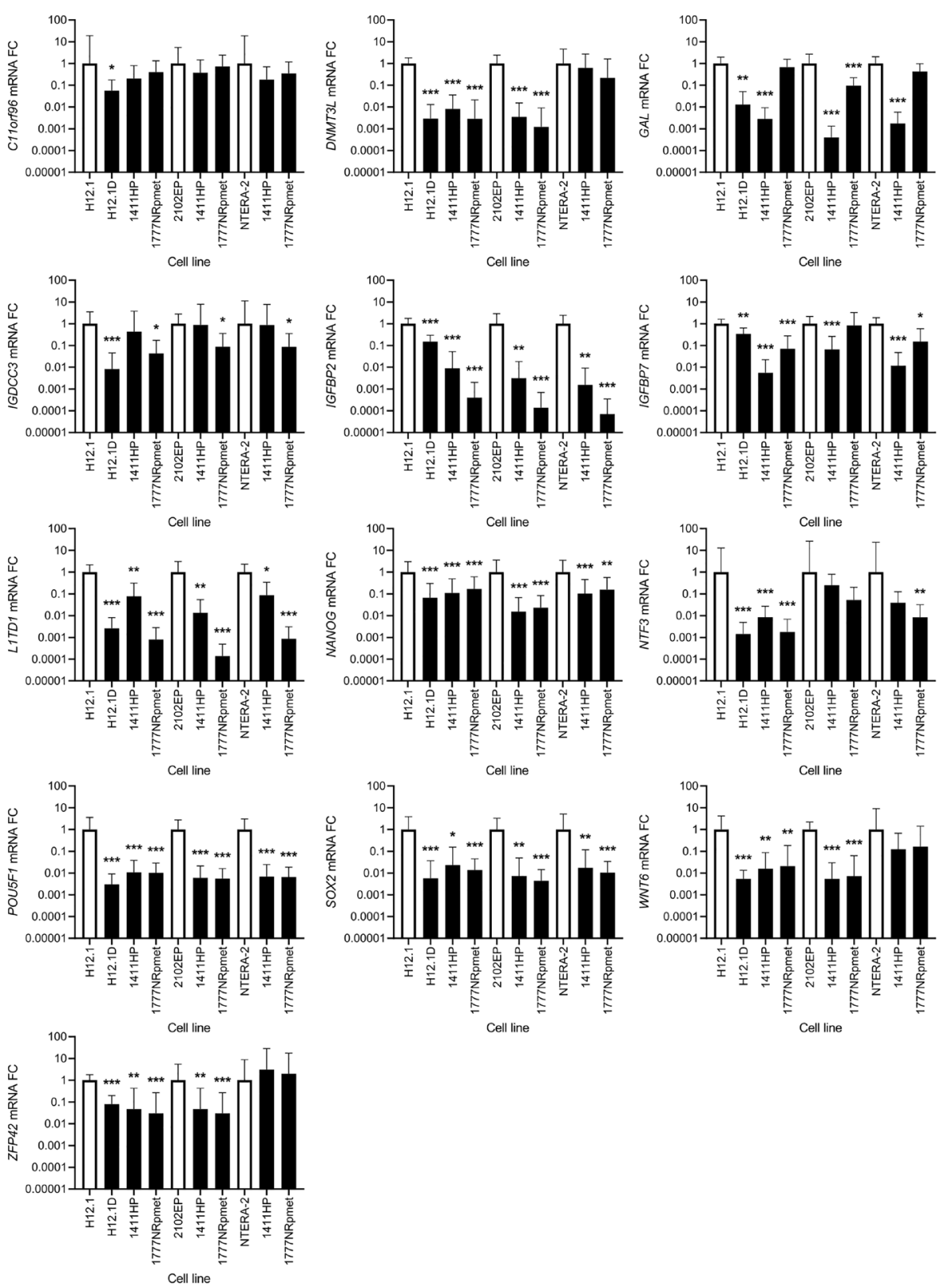

Figure 5: Expression change of 13 candidate genes that were originally identified as down-regulated using gene expression array. CDDP-resistant (H12.1D, 1411HP and 1777NRpmet) and -sensitive (H12.1, 2102EP and NTERA-2) TGCT cell lines are represented as black and white bars, respectively. Error bars represent upper and lower limits of expression of three technical and three biological replicates. ${ }^{*} p \leq 0.05,{ }^{* *} p \leq 0.01,{ }^{* * *} p \leq 0.001$. 
line. CYB5A has a key role in lipid-radical cycles in membranes, leading to positive effects on microsomal and mitochondrial oxidation [78]. CYB5R2 is a cytochrome b5 reductase 2 , methylation of which in nasopharyngeal carcinoma was associated with lymph node metastasis [79]. The increased expression observed in the present study might suggest a role of CYB5A and CYB5R2 in metabolic alterations causing CDDP-resistant phenotype and metastatic progression in TGCTs. Since CCN1 showed a similar trend in the expression level in metastasisderived cell lines, it may also play a role in metastatic spread in TGCTs. Accordingly, it has been reported to act as a key inducing factor in the metastatic progression and chemoresistance in some other cancer types [80, 81]. FADS2 is a protein involved in an unknown plasticity of the lipid metabolism of some tumor types [82], suggesting another metabolism modification leading to chemoresistant phenotype in TGCTs. ID2 was significantly overexpressed in all CDDP-resistant TGCT cell lines. In other cancers, the ID2 protein promotes early-stage progression [83] and survival during metabolic stress [84], and its defect leads to a more differentiated less aggressive phenotype [85]. We found no significant changes in ISG20 expression, although ISG20 is a protein whose forced expression leads to significant promotion of metastasis and angiogenesis in hepatocellular carcinoma [86]. The consistent overexpression of PCP4 in all CDDP-resistant TGCT cell lines may parallel observation showing that $\mathrm{PCP} 4$ regulates apoptosis in breast cancer cells [87]. We revealed no significant difference in expression of $R E C 8$, which has tumor suppressive effects partially mediated by down-regulation of genes involved

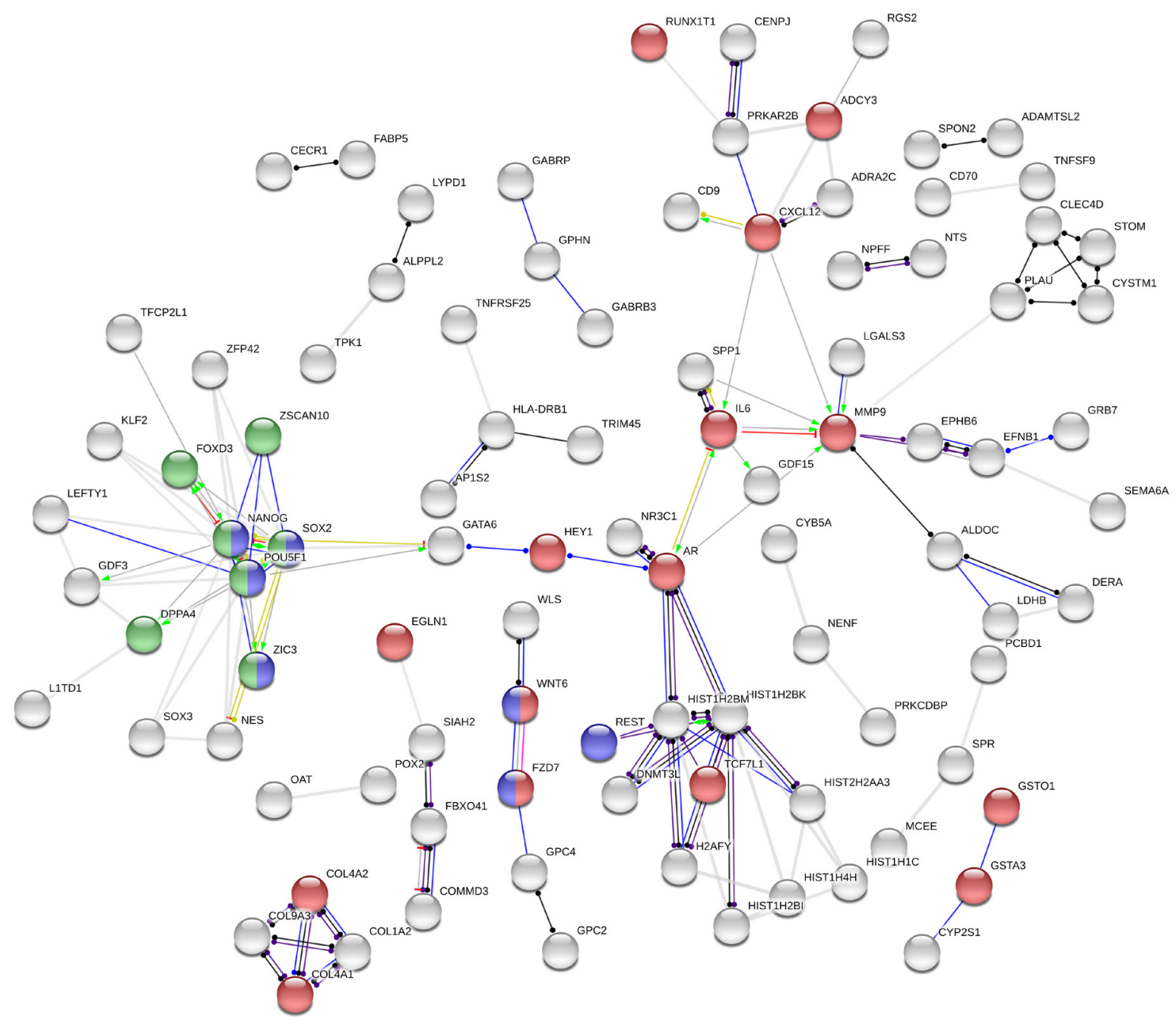

Figure 6: Association network in STRING. Out of 281 genes, 247 proteins were recognized by the STRING database and additional 152 were hidden as disconnected nodes, when the confidence level has been set to 'high' (0.700). Coloured nodes represent at least one of the three selected functional enrichment network categories: (i) pathways in cancer (KEGG pathways database; red); (ii) signaling pathways regulating pluripotency of stem cells (KEGG pathways database; blue), and (iii) transcriptional regulation of pluripotent stem cells (Reactome pathways database; green). Action types: activation (green), binding (blue), inhibition (red), phenotype (cyan), reaction (black), catalysis (purple), post-translational modification (magenta) and transcriptional regulation (yellow). Action effects: positive (arrow; $\rightarrow$ ), negative (capped line; $\stackrel{\perp}{ }$ ) and unspecified (dot; $\bullet$ ). 
in cell growth and up-regulation of apoptosis/migration inhibitors [88], accounting for the lack of its tumor suppressive effect in TGCTs. SLC40A1 expression was consistently up-regulated in all resistant TGCT cell lines. SLC40A1 is an iron exporter possessing many putative Nrf2 binding sites. Elevated levels of Nrf2 and reduced levels of SLC40A1 were previously found in CDDPresistant ovarian cancer cells [89], contradictory to our findings, indicating different iron needs and transport modification in TGCTs. Hence, the increased expression of iron transporters may contribute to CDDP-resistance via pre-target mechanism of resistance [14] in this malignity, where copper transporters ATP7A and ATP7B are overexpressed and contribute to CDDP-resistance [90]. However, further work is required to verify this assumption. We found significantly increased expression of TMSB $4 X$ in $1411 \mathrm{HP}$ and $1777 \mathrm{NRpmet}$, but decreased expression in H12.1D TGCT cell line, compared to H12.1. In ovarian cancer, increased levels of this protein play a role in accelerating proliferation, invasion and migration [91]. This protein is also a candidate biomarker in head and neck squamous cell carcinomas [92]. According to our results, TMSB4X might be able of discriminating between the intrinsic and acquired resistance, as it was up-regulated only in metastasis-derived TGCT cell lines, which were isolated from patients with multidrug/intrinsic resistance towards CDDP. TRIB3 plays an important role in cancer by inhibiting proliferation, as TRIB3 silencing significantly inhibited $\mathrm{HaCaT}$ cell proliferation [93], knockdown inhibited lung cancer cell migration, invasion, epithelial-mesenchymal transition and stemness [94], and its elevated levels supported breast cancer progression [95]. As it was up-regulated in all CDDP-resistant TGCT cell lines, its role in TGCT cell proliferation and migration is also highly expected.

Of course, we are aware of the fact that our study has some limitations. These result mainly from the combination of cell lines used, as only one pair of TGCT cell lines originates from the same cell clone and resistant derivative was not really made CDDPresistant, for instance by cultivation with sub-lethal doses of this drug, as used in recent works in the field [96-98]. Instead, the parental CDDP-sensitive cell line was in vitro differentiated using differentiation-inducing medium. Other pairs combine non-isogenic cell lines. In general, differentiation or losing the embryonal pluripotent state does induce CDDP resistance. However, in the case of H12.1D, the differentiation is towards somatic lineages, and therefore more resembles teratoma, which is not that clinical problem. The 1411HP cells have lost the pluripotent state, are CDDP resistant and show malignant growth in nude mice. The tumor consists of undifferentiated carcinoma with EC-like morphology and differentiation features of YST. We propose that it is an extra-embryonal progenitor [46]. It more represents the clinically relevant CDDP resistant malignant TGCT type.
Both metastasis-derived TGCT cell lines represent models with natural (true) resistance which can also be considered as an advantage compared to the models with artificially established resistance. With the $1411 \mathrm{HP}$, we investigated a model which can represent a "resistant non-teratoma tumor". Nevertheless, resistance marker found in H12.1D might be useful to investigate resistance mechanisms in other cells.

\section{MATERIALS AND METHODS}

\section{Cell cultures}

H12.1, 2102EP, H12.1D, 1411HP and 1777NRpmet TGCT cell lines (Table 1) were grown in RPMI-1640 medium supplemented with $10 \%$ fetal bovine serum (FBS), penicillin (100 units/ml) and streptomycin $(10 \mu \mathrm{l} /$ $\mathrm{ml}$ ). NTERA-2 TGCT cell line (Table 1) was grown in Dulbecco's modified eagle's medium supplemented with F-10 nutrient mixture $(1: 1), 10 \% \mathrm{FBS}$, penicillin (100 units $/ \mathrm{ml})$ and streptomycin $(10 \mu \mathrm{l} / \mathrm{ml})$. Cell lines were cultivated at $37^{\circ} \mathrm{C}$ in $5 \% \mathrm{CO}_{2}$ atmosphere.

\section{MTT assay}

Viability of TGCT cell lines after CDDP treatment was determined by the MTT assay. Briefly, $5 \times 10^{3}$ cells were seeded into 96-well plate and allowed to grow/ attach for $24 \mathrm{hr}$. The cells were treated with the increasing concentrations of CDDP in culture medium for $24 \mathrm{hr}$. Cells were then washed with PBS and MTT $(1 \mathrm{mg} / \mathrm{ml})$ was added to cell suspensions. The cells were incubated with MTT for $4 \mathrm{hr}$. Afterwards, MTT was discarded, and DMSO was added to dissolve formazan crystals. The resulting absorbance was measured at wavelength of 540 and $690 \mathrm{~nm}$ with xMark $^{\mathrm{TM}}$ Microplate Spectrophotometer (Bio-Rad Laboratories, Inc.). The $\mathrm{IC}_{50}$ values were determined by GraphPad Prism (version 8.4.3).

\section{RNA extraction}

To extract the total RNA, TRI Reagent solution (Life Technologies) was used. Total RNA was quantified using MaestroNano Spectrophotometer (Applied Biological Materials Inc.) and Qubit fluorometer (Qubit ${ }^{\circledR}$ RNA HS Assay Kit, Life Technologies). RNA integrity was assessed using the Agilent 2100 bioanalyzer (Agilent, Palo Alto, CA, USA). Extracted RNA was used for microarray analysis and RT-qPCR validation.

\section{Gene expression profiling}

Genome-wide gene expression analysis was performed using Agilent SurePrint G3 Human Gene Expression v3 8x60K Microarray kit (product \# G4851C, design ID 072363, Agilent Technologies). Each array 
contained 60-mer oligonucleotide probes for 26,083 unique genes/transcripts and 30,606 unique lncRNAs. One-color microarray-based gene expression analysis was conducted according to the manufacturer's instructions. Briefly, $200 \mathrm{ng}$ of total RNA from each sample was used. After annealing of the T7 promoter primer to the total RNA, the samples were incubated and labelled with Cy3-CTP to perform reverse transcription according to the original protocol (One-Color Microarray-Based Gene Expression Analysis ver.6.9, G414090040). The labelled samples were hybridized onto the SurePrint G3 Human Gene Expression microarray in the Agilent Microarray Hybridization Chamber (G2534) for $20 \mathrm{~h}$ at $65^{\circ} \mathrm{C} / 20 \mathrm{rpm}$ in a rotator oven. After washing with the Gene Expression Wash Buffers 1 and 2 (5188-5327) and drying, slides were scanned in the Innoscan 900 microarray scanner (Innopsys Inc., Carbonne, France) with the resolution of 3 micrometers. The resulting images of individual arrays were extracted with the Mapix 7.3.0 software (Innopsys Inc., Carbonne, France) and exported as GPR files. For each TGCT cell line, gene expression arrays were repeated for 3 individual biological replicates.

To determine gene expression from GPR files, correction of background/signal to noise ratio was performed to output values, and probe signal summarization to the level of individual gene expression was applied. In the next step, the corrected differentially expressed genes were identified by limma package, and FC of gene expression in CDDP-resistant vs -sensitive TGCT cell lines were calculated, along with average expression and $p$ values, in order to identify difference in gene expression of CDDP-resistant TGCT cell lines.

For result interpretation, we consider gene expression to be up-regulated, when ratio in the mean mRNA expression/FC of CDDP-resistant vs -sensitive TGCT cell line was $>1$, and down-regulated, when the mean FC between CDDP-resistant and -sensitive TGCT cell line was $<1$. This is due to the fact, that after microarray visualization, and correction to background noise, we compared the corrected resulting signals (representing gene expression in samples) as proportion/ difference in average expression in CDDP-resistant TGCT cell line vs -sensitive one (H12.1).

\section{RT-qPCR validation}

The altered expression of the selected genes identified in microarray analysis was validated using SYBR Green-based qPCR. Differentially expressed genes were evaluated by RT-qPCR using First-Strand cDNA Synthesis System (Central European Biosystems, Czech Republic). Briefly, for cDNA synthesis in a reaction of a final volume of $20 \mu \mathrm{l}, 1,500 \mathrm{ng}$ of total RNA, $2 \mu \mathrm{l}$ of $10 \mathrm{x}$ MuLV buffer, $1 \mu \mathrm{M}$ of $\mathrm{p}(\mathrm{dN}) 6$ primer, $0.1 \mathrm{mM}$ of $\mathrm{dNTP}$ mixture and 100 units of MuLV reverse transcriptase were incubated at $42^{\circ} \mathrm{C}$ for $1 \mathrm{hr}$ followed by enzyme inactivation at $95^{\circ} \mathrm{C}$ for $5 \mathrm{~min}$. RT-qPCR detection and quantification of the selected genes and the $P G K 1$ and $\beta$-actin reference genes was performed using SYBR Premix Ex Taq II (Tli RNaseH Plus), ROX plus (Takara, Japan) and specific reverse and forward primers listed in Supplementary Table 9. qPCR was performed using Agilent, ARIA RealTime PCR System (Agilent) at following setting: $95^{\circ} \mathrm{C}$ for $5 \mathrm{~min}$, followed by 40 cycles of $95^{\circ} \mathrm{C}$ for $20 \mathrm{sec}$ and $60^{\circ} \mathrm{C}$ for $50 \mathrm{sec}$, followed by melt cycle. All samples were amplified in triplicates. Ct values were averaged and normalized against reference endogenous genes $P G K 1$ and $\beta$-actin, stably expressed across all TGCT cell lines tested. The average $\mathrm{Ct}$ value of $P G K 1$ was $22.8 \pm 1.29$ for CDDPsensitive and $23.05 \pm 1.58$ for -resistant TGCT cell lines; average $\mathrm{Ct}$ value for $\beta$-actin in CDDP-sensitive TGCT cell lines was $17.18 \pm 0.98$ and for -resistant TGCT cell lines $16.67 \pm 0.81$.

\section{Statistical analysis}

For statistical analysis of the gene expression data, SigmaPlot 12.5 and Prism GraphPad 8.4.3 were used. Normality of distribution was tested by the Shapiro-Wilk test. Relative quantification of the gene expression was calculated with $2^{-\Delta \Delta \mathrm{Ct}}$ method, which represents relative FCs of expression. Therefore, $\Delta \Delta \mathrm{Ct}=\Delta \mathrm{Ct}$ (CDDPresistant cell line) - $\Delta \mathrm{Ct}$ (CDDP-sensitive cell line). Analysis of the significance of FC in the gene expression between the studied groups was applied to the $\Delta \mathrm{Ct}$ values. If normally distributed, gene expression data were tested by analysis of variance (ANOVA) with the Bonferroni's post-hoc test for multiple comparisons. If data were normally distributed but did not pass Levene' test for equality of variances, One-way ANOVA was used with Tamhane's T2 test for multiple comparisons. If the data were non-normally distributed, Kruskal-Wallis One Way ANOVA with Dunn's test for multiple comparisons was used. All tests were two-tailed, performed at the significance level $\alpha=0.05$. For all analyses, $p<0.05$ was considered statistically significant $\left({ }^{*} p<0.05 ;{ }^{* *} p<0.01\right.$, $\left.{ }^{* * *} p<0.001\right)$. Graphic output in the form of a heatmap for gene expression microarray analysis was performed using RStudio (RStudio, Inc.; version 1.2.1335). The cut-off of significantly up- or down-regulated genes was selected according to their log FC and adjusted $p$ value in abovementioned software and imported into RStudio. Heatmap dendrogram creation parameters were set based on data similarity.

To conduct predictive interactome analysis, STRING v 11 [99] was used (https://string-db.org). Out of 281 genes (the overlapping genes from gene expression microarray, which had $>2 \mathrm{FC}$ and adjusted $p$ value $<0.05), 247$ proteins were recognized by the STRING database. Interactome settings were as follows: (i) meaning of network edges was set to molecular action (line shape indicates the predicted mode of action); (ii) 
interaction channels, i.e., text-mining, experiments, databases, co-expression, neighborhood, gene fusion and co-occurrence, were active; and (iii) minimum required interaction score was set to high confidence (0.700).

\section{CONCLUSIONS}

In the present study, we compared gene expression profiles in the group of CDDP-resistant and -sensitive TGCT cell lines using gene expression array. We identified 281 genes, which were significantly de-regulated in CDDP-resistant compared to -sensitive TGCT cell lines. Of them, 247 were recognized by the STRING database. Based on the generated association, three main categories were identified as important for CDDP response in TGCT cells, pathways relevant for cancer in general, signaling pathways regulating pluripotency of stem cells, and transcriptional regulation of pluripotent stem cells (Figure 6). 25 genes with the highest expression change were validated using RT-qPCR. The $D N M T 3 L, G A L$, IGFBP2, IGFBP7, L1TD1, NANOG, NTF3, POU5F1, SOX2, WNT6, ZFP42, ID2, PCP4, SLC40A1 and TRIB3 genes displayed comparable expression change in both gene expression array and RT-qPCR experiment. We propose that the identified genes, whose expression is stably changed across all CDDP-resistant TGCT cell lines, independently of the origin of resistance, could after clinical validation serve as prognostic markers for early detection of CDDP response and for timely and precisely treatment optimization.

\section{Abbreviations}

TGCT: Testicular germ cell tumor; CDDP: cisplatin; SE: seminoma; NSE: non-seminoma; EC: embryonal carcinoma; CC: choriocarcinoma; YST: yolk sac tumor; TE: teratoma; DDR: DNA damage response; NER: nucleotide excision repair; AFP: $\alpha$-fetoprotein; IGCCCG: International Germ Cell Cancer Cooperative Group; MTT: (3-(4,5-dimethylthiazol-2-yl)-2,5diphenyltetrazolium bromide; FBS: fetal bovine serum; FC: fold change; ANOVA: analysis of variance; IC: inhibitory concentration; GCT: germ cell tumor; HERVK: human endogenous retrovirus $\mathrm{K}$ sequences; DMSO: dimethyl sulfoxide.

\section{Author contributions}

$\mathrm{MC}$ and DJ conceived and designed the study. DJ, JR, Z $\breve{S}, \mathrm{LW}$ and $\mathrm{LH}$ acquired data. DJ, JR and MC analyzed and interpreted data. JR and DJ performed statistical analysis. MC and JR wrote first draft of the manuscript and DJ and TM critically revised the manuscript. MC and DJ obtained funding and supervised the whole study. All authors read and approved the final manuscript.

\section{CONFLICTS OF INTEREST}

Authors have no conflicts of interest to declare.

\section{FUNDING}

This work was supported by the VEGA Grant Agency of the Slovak Republic (grants no. 2/0108/17 and 2/0053/19), the Slovak Research and Development Agency (grant no. APVV-17-0384), the Ministry of Education, Science, Research and Sport of the Slovak Republic (grant no. MVTS-34097104) and the Ministry of Health of the Slovak Republic (grant no. 2019/57-BMCSAV-1).

\section{REFERENCES}

1. Bray F, Ferlay J, Devesa SS, McGlynn KA, Moller H. Interpreting the international trends in testicular seminoma and nonseminoma incidence. Nat Clin Pract Urol. 2006; 3:532-543. https://doi.org/10.1038/ncpuro0606. [PubMed]

2. Woldu SL, Bagrodia A. Update on epidemiologic considerations and treatment trends in testicular cancer. Curr Opin Urol. 2018; 28:440-447. https://doi.org/10.1097/ mou.0000000000000532. [PubMed]

3. Batool A, Karimi N, Wu XN, Chen SR, Liu YX. Testicular germ cell tumor: a comprehensive review. Cell Mol Life Sci. 2019; 76:1713-1727. https://doi.org/10.1007/s00018019-03022-7. [PubMed]

4. di Pietro A, de Vries EGE, Gietema JA, Spierings DCJ, de Jong S. Testicular germ cell tumours: the paradigm of chemo-sensitive solid tumours. Int J Biochem Cell Biol. 2005; 37:2437-2456. https://doi.org/10.1016/j. biocel.2005.06.014. [릴ed]

5. Lobo J, Jeronimo C, Henrique R. Cisplatin resistance in testicular germ cell tumors: Current challenges from various perspectives. Cancers (Basel). 2020; 12:1601. https://doi. org/10.3390/cancers12061601. [PubMed]

6. Einhorn LH, Williams SD, Chamness A, Brames MJ, Perkins SM, Abonour R. High-dose chemotherapy and stem-cell rescue for metastatic germ-cell tumors. N Engl J Med. 2007; 357:340-348. https://doi.org/10.1056/ nejmoa067749. [PubMed]

7. Feldman DR, Bosl GJ, Sheinfeld J, Motzer RJ. Medical treatment of advanced testicular cancer. JAMA. 2008; 299:672684. https://doi.org/10.1001/jama.299.6.672. [PubMed]

8. Oosterhuis JW, Looijenga LH. Testicular germ-cell tumours in a broader perspective. Nat Rev Cancer. 2005; 5:210-222. https://doi.org/10.1038/nrc1568. [PubMed]

9. Moch H, Cubilla AL, Humphrey PA, Reuter VE, Ulbright TM. The 2016 WHO classification of tumours of the urinary system and male genital organs - Part A: Renal, penile, and testicular tumours. Eur Urol. 2016; 70:93-105. https://doi. org/10.1016/i.eururo.2016.02.029. [PubMed] 
10. Winter C, Albers P. Testicular germ cell tumors: pathogenesis, diagnosis and treatment. Nat Rev Endocrinol. 2011; 7:43-53. https://doi.org/10.1038/nrendo.2010.196. [PubMed]

11. Cheng L, Albers P, Berney DM, Feldman DR, Daugaard G, Gilligan T, Looijenga LHJ. Testicular cancer. Nat Rev Dis Primers. 2018; 4:29. https://doi.org/10.1038/s41572-0180029-0. [PubMed]

12. Boccellino M, Vanacore D, Zappavigna S, Cavaliere C, Rossetti S, D'Aniello C, Chieffi P, Amler E, Buonerba C, Di Lorenzo G, Di Franco R, Izzo A, Piscitelli R, et al. Testicular cancer from diagnosis to epigenetic factors. Oncotarget. 2017; 8:104654-104663. https://doi. org/10.18632/oncotarget.20992. [PubMed]

13. Oosterhuis JW, Looijenga LHJ. Human germ cell tumours from a developmental perspective. Nat Rev Cancer. 2019; 19:522-537. https://doi.org/10.1038/s41568-019-0178-9. [PubMed]

14. Galluzzi L, Senovilla L, Vitale I, Michels J, Martins I, Kepp O, Castedo M, Kroemer G. Molecular mechanisms of cisplatin resistance. Oncogene. 2012; 31:1869-1883. https://doi.org/10.1038/onc.2011.384. [PubMed]

15. Noll DM, Mason TM, Miller PS. Formation and repair of interstrand cross-links in DNA. Chem Rev. 2006; 106:277301. https://doi.org/10.1021/cr040478b. [PubMed]

16. O'Connor PM, Kohn KW. Comparative pharmacokinetics of DNA lesion formation and removal following treatment of L1210 cells with nitrogen mustard. Cancer Commun. 1990; 2:387-394. https://doi.org/10.3727/095535490820873949. [PubMed]

17. Friboulet L, Olaussen KA, Pignon JP, Shepherd FA, Tsao MS, Graziano S, Kratzke R, Douillard JY, Seymour L, Pirker R, Filipits M, André F, Solary E, et al. ERCC1 isoform expression and DNA repair in non-small-cell lung cancer. N Engl J Med. 2013; 368:1101-1110. https://doi. org/10.1056/nejmoa1214271. [PubMed]

18. Handra-Luca A, Hernandez J, Mountzios G, Taranchon E, Lacau-St-Guily J, Soria JC, Fouret P. Excision repair cross complementation group 1 immunohistochemical expression predicts objective response and cancer-specific survival in patients treated by cisplatin-based induction chemotherapy for locally advanced head and neck squamous cell carcinoma. Clin Cancer Res. 2007; 13:3855-3859. https:// doi.org/10.1158/1078-0432.ccr-07-0252. [PubMed]

19. Dabholkar M, Bostick-Bruton F, Weber C, Bohr VA, Egwuagu C, Reed E. ERCC1 and ERCC2 expression in malignant tissues from ovarian cancer patients. J Natl Cancer Inst. 1992; 84:1512-1517. https://doi.org/10.1093/ jnci/84.19.1512. [PubMed]

20. Metzger R, Leichman CG, Danenberg KD, Danenberg PV, Lenz HJ, Hayashi K, Groshen S, Salonga D, Cohen H, Laine L, Crookes P, Silberman H, Baranda J, et al. ERCC1 mRNA levels complement thymidylate synthase mRNA levels in predicting response and survival for gastric cancer patients receiving combination cisplatin and fluorouracil chemotherapy. J Clin Oncol. 1998; 16:309-316. https://doi. org/10.1200/jco.1998.16.1.309. [PubMed]

21. Bellmunt J, Paz-Ares L, Cuello M, Cecere FL, Albiol S, Guillem V, Gallardo E, Carles J, Mendez P, de la Cruz JJ, Taron M, Rosell R, Baselga J, and Spanish Oncology Genitourinary Group. Gene expression of ERCC1 as a novel prognostic marker in advanced bladder cancer patients receiving cisplatin-based chemotherapy. Ann Oncol. 2007; 18:522-528. https://doi.org/10.1093/annonc/ mdl435. [PubMed]

22. Mendoza J, Martínez J, Hernández C, Pérez-Montiel D, Castro C, Fabián-Morales E, Santibáñez M, GonzálezBarrios R, Díaz-Chávez J, Andonegui MA, Reynoso N, Oñate LF, Jiménez MA, et al. Association between ERCC1 and XPA expression and polymorphisms and the response to cisplatin in testicular germ cell tumours. Br J Cancer. 2013; 109:68-75. https://doi.org/10.1038/bjc.2013.303. [PubMed]

23. Honecker F, Mayer F, Stoop H, Oosterhuis JW, Koch S, Bokemeyer C, Looijenga LHJ. Xeroderma pigmentosum group A protein and chemotherapy resistance in human germ cell tumors. Lab Invest. 2003; 83:1489-1495. https:// doi.org/10.1097/01.lab.0000090221.95883.41. [PubMed]

24. Koberle B, Brenner W, Albers A, Usanova S, Thuroff JW, Kaina B. ERCC1 and XPF expression in human testicular germ cell tumors. Oncol Rep. 2010; 23:223-227. [PubMed]

25. Koberle B, Masters JRW, Hartley JA, Wood RD. Defective repair of cisplatin-induced DNA damage caused by reduced XPA protein in testicular germ cell tumours. Curr Biol. 1999; 9:273-276. https://doi.org/10.1016/s09609822(99)80118-3. [PubMed]

26. Welsh C, Day R, McGurk C, Masters JR, Wood RD, Koberle B. Reduced levels of XPA, ERCC1 and XPF DNA repair proteins in testis tumor cell lines. Int J Cancer. 2004; 110:352-361. https://doi.org/10.1002/ijc.20134. [PubMed]

27. Cierna Z, Miskovska V, Roska J, Jurkovicova D, Pulzova Borszekova L, Sestakova Z, Hurbanova L, Machalekova K, Chovanec M, Rejlekova K, Svetlovska D, Kalavska K, Kajo K, et al. Increased levels of XPA might be the basis of cisplatin resistance in germ cell tumours. BMC Cancer. 2020; 20:17. https://doi.org/10.1186/s12885-019-6496-1. [PubMed]

28. Barlow LJ, Badalato GM, McKiernan JM. Serum tumor markers in the evaluation of male germ cell tumors. Nat Rev Urol. 2010; 7:610-617. https://doi.org/10.1038/ nrurol.2010.166. [PubMed]

29. International Germ Cell Cancer Collaborative Group (IGCCCG). The International Germ Cell Consensus Classification: A prognostic factor based staging system for metastatic germ cell cancer. J Clin Oncol. 1997; 15:594-603. https://doi.org/10.1200/jco.1997.15.2.594. [PubMed]

30. Skotheim RI, Autio R, Lind GE, Kraggerud SM, Andrews PW, Monni O, Kallioniemi O, Lothe RA. Novel genomic aberrations in testicular germ cell tumors by array-CGH, and associated gene expression changes. Cell Oncol. 2006; 28:315-326. https://doi.org/10.1155/2006/219786. [PubMed] 
31. Duale N, Lindeman B, Komada M, Olsen AK, Andreassen A, Soderlund EJ, Brunborg G. Molecular portrait of cisplatin induced response in human testis cancer cell lines based on gene expression profiles. Mol Cancer. 2007; 6:53. https://doi.org/10.1186/1476-4598-6-53. [ubMed]

32. Noel EE, Yeste-Velasco M, Mao X, Perry J, Kudahetti SC, Li NF, Sharp S, Chaplin T, Xue L, McIntyre A, Shan L, Powles T, Oliver TD, et al. The association of CCND1 overexpression and cisplatin resistance in testicular germ cell tumors and other cancers. Am J Pathol. 2010; 176:2607-15. https://doi.org/10.2353/ajpath.2010.090780. [PubMed]

33. Schaffrath J, Schmoll HJ, Voigt W, Müller LP, MüllerTidow C, Mueller T. Efficacy of targeted drugs in germ cell cancer cell lines with differential cisplatin sensitivity. PLoS One. 2017; 12:e0178930. https://doi.org/10.1371/journal. pone.0178930. [PubMed]

34. Mueller T, Mueller LP, Luetzkendorf J, Voigt W, Simon $\mathrm{H}$, Schmoll HJ. Loss of Oct-3/4 expression in embryonal carcinoma cells is associated with induction of cisplatin resistance. Tumour Biol. 2006; 27:71-83. https://doi. org/10.1159/000092324. [PubMed]

35. Vogelzang NJ, Bronson D, Savino D, Vessella RL, Fraley EF. A human embryonal-yolk sac carcinoma model system in athymic mice. Cancer. 1985; 55:2584-2593. https://doi. org/10.1002/1097-0142(19850601)55:11\%3C2584::aidcncr2820551110\%3E3.0.co;2-b. [PubMed]

36. Bronson DL, Vessella RL, Fraley EE. Differentiation potential of human embryonal carcinoma cell lines. Cell Differ. 1984; 15:129-132. https://doi.org/10.1016/00456039(84)90064-2. [PubMed]

37. Casper J, Schmoll HJ, Schnaidt U, Fonatsch C. Cell lines of human germinal cancer. Int J Androl. 1987; 10:105113. https://doi.org/10.1111/j.1365-2605.1987.tb00171.x. [PubMed]

38. Andrews PW, Bronson DL, Benham F, Strickland S, Knowles BB. A comparative study of eight cell lines derived from human testicular teratocarcinoma. Int J Cancer. 1980; 26:269280. https://doi.org/10.1002/ijc.2910260304. [PubMed]

39. Wang N, Trend B, Bronson DL, Fraley EE. Nonrandom abnormalities in chromosome 1 in human testicular cancers. Cancer Res. 1980; 40:796-802. [PubMed]

40. Andrews PW, Goodfellow PN, Shevinsky LH, Bronson DL, Knowles BB. Cell-surface antigens of a clonal human embryonal carcinoma cell line: morphological and antigenic differentiation in culture. Int J Cancer. 1982; 29:523-531. https://doi.org/10.1002/ijc.2910290507. [PubMed]

41. Giesberts AN, Duran C, Morton IN, Pigott C, White SJ, Andrews PW. The expression and function of cadherinmediated cell-to-cell adhesion in human embryonal carcinoma cells. Mech Dev. 1999; 83:115-125. https://doi. org/10.1016/s0925-4773(99)00043-x. [PubMed]

42. Andrews PW. Retinoic acid induces neuronal differentiation of a cloned human embryonal carcinoma cell line in vitro.
Dev Biol. 1984; 103:285-293. https://doi.org/10.1016/00121606(84)90316-6. [PubMed]

43. Andrews PW, Damjanov I, Simon D, Banting GS, Carlin C, Dracopoli NC, Føgh J. Pluripotent embryonal carcinoma clones derived from the human teratocarcinoma cell line Tera-2. Differentiation in vivo and in vitro. Lab Invest. 1984; 50:147-162. [PubMed]

44. Pleasure SJ, Lee VM. NTera 2 cells: a human cell line which displays characteristics expected of a human committed neuronal progenitor cell. J Neurosci Res. 1993; 35:585-602. https://doi.org/10.1002/jnr.490350603. [PubMed]

45. Mueller T, Voigt W, Simon H, Fruehauf A, Bulankin A, Grothey A, Schmoll HJ. Failure of activation of caspase-9 induces a higher threshold for apoptosis and cisplatin resistance in testicular cancer. Cancer Res. 2003; 63:513521. [PubMed]

46. Mueller T, Mueller LP, Holzhausen HJ, Witthuhn R, Albers $\mathrm{P}$, Schmoll HJ. Histological evidence for the existence of germ cell tumor cells showing embryonal carcinoma morphology but lacking OCT4 expression and cisplatin sensitivity. Histochem Cell Biol. 2010; 134:197-204. https://doi.org/10.1007/s00418-010-0710-1. [PubMed]

47. Abada PB, Howell SB. Cisplatin induces resistance by triggering differentiation of testicular embryonal carcinoma cells. PLoS One. 2014; 9:e87444. https://doi.org/10.1371/ journal.pone.0087444. [PubMed]

48. Yu DH, Fan W, Liu G, Nguy V, Chatterton JE, Long S, Ke N, Meyhack B, Bruengger A, Brachat A, Wong-Staal F, Li QX. PHTS, a novel putative tumor suppressor, is involved in the transformation reversion of HeLaHF cells independently of the p53 pathway. Exp Cell Res. 2006; 312:865-876. https:// doi.org/10.1016/j.yexcr.2005.12.006. [PubMed]

49. Wikman H, Sielaff-Frimpong B, Kropidlowski J, Witzel I, Milde-Langosch K, Sauter G, Westphal M, Lamszus K, Pantel K. Clinical relevance of loss of $11 \mathrm{p} 15$ in primary and metastatic breast cancer: association with loss of PRKCDBP expression in brain metastases. PLoS One. 2012; 7:e47537. https://doi.org/10.1371/journal.pone.0047537. [PubMed]

50. Lee JH, Kang MJ, Han HY, Lee MG, Jeong SI, Ryu BK, Ha TK, Her NG, Han J, Park SJ, Lee KY, Kim HJ, Chi SG. Epigenetic alteration of PRKCDBP in colorectal cancers and its implication in tumor cell resistance to TNF $\alpha$-induced apoptosis. Clin Cancer Res. 2011; 17:7551-7562. https:// doi.org/10.1158/1078-0432.ccr-11-1026. [PubMed]

51. Lee JH, Byun DS, Lee MG, Ryu BK, Kang MJ, Chae KS, Lee KY, Kim HJ, Park H, Chi SG. Frequent epigenetic inactivation of hSRBC in gastric cancer and its implication in attenuated p53 response to stresses. Int J Cancer. 2008; 122:1573-1584. https://doi.org/10.1002/ijc.23166. [PubMed]

52. $\mathrm{Xu} \mathrm{XL}, \mathrm{Wu} \mathrm{LC}, \mathrm{Du} F$, Davis A, Peyton M, Tomizawa Y, Maitra A, Tomlinson G, Gazdar AF, Weissman BE, Bowcock AM, Baer R, Minna JD. Inactivation of human SRBC, located within the 11p15.5-p15.4 tumor suppressor region, in breast and lung cancers. Cancer Res. 2001; 61:7943-7949. [ㄹuMed] 
53. Tong SY, Ki KD, Lee JM, Kang MJ, Ha TK, Chung SI, Chi SG, Lee SK. Frequent inactivation of hSRBC in ovarian cancers by promoter $\mathrm{CpG}$ island hypermethylation. Acta Obstet Gynecol Scand. 2010; 89:629-635. https://doi. org/10.3109/00016341003678443. [ [PubMed]

54. Bai L, Deng X, Li Q, Wang M, An W, Deli A, Gao Z, Xie Y, Dai Y, Cong YS. Down-regulation of the cavin family proteins in breast cancer. J Cell Biochem. 2012; 113:322328. https://doi.org/10.1002/jcb.23358. [PubMed]

55. Looijenga LH, Stoop H, de Leeuw HP, de Gouveia Brazao CA, Gillis AJ, van Roozendaal KE, van Zoelen EJ, Weber RF, Wolffenbuttel KP, van Dekken H, Honecker F, Bokemeyer C, Perlman EJ, et al. POU5F1 (OCT3/4) identifies cells with pluripotent potential in human germ cell tumors. Cancer Res. 2003; 63:2244-2250. [PubMed]

56. de Jong J, Stoop H, Gillis AJ, van Gurp RJ, van de Geijn GJ, Boer dM, Hersmus R, Saunders PT, Anderson RA, Oosterhuis JW, Looijenga LH. Differential expression of SOX17 and SOX2 in germ cells and stem cells has biological and clinical implications. J Pathol. 2008; 215:2130. https://doi.org/10.1002/path.2332. [PubMed]

57. Mueller T, Luetzkendorf J, Nerger K, Schmoll HJ, Mueller LP. Analysis of OCT4 expression in an extended panel of human tumor cell lines from multiple entities and in human mesenchymal stem cells. Cell Mol Life Sci. 2009; 66:495503. https://doi.org/10.1007/s00018-008-8623-z. [PubMed]

58. Mueller T, Hantsch C, Volkmer I, Staege MS. Differentiation-dependent regulation of human endogenous retrovirus $\mathrm{K}$ sequences and neighboring genes in germ cell tumor cells. Front Microbiol. 2018; 9:1253. https://doi. org/10.3389/fmicb.2018.01253. [PubMed]

59. Hauptman N, Bostjancic E, Zlajpah M, Rankovic B, Zidar N. Bioinformatics analysis reveals most prominent gene candidates to distinguish colorectal adenoma from adenocarcinoma. Biomed Res Int. 2018; 2018:9416515. https://doi.org/10.1155/2018/9416515. [PubMed]

60. Manderwad GP, Gokul G, Kannabiran C, Honavar SG, Khosla S, Vemuganti GK. Hypomethylation of the DNMT3L promoter in ocular surface squamous neoplasia. Arch Pathol Lab Med. 2010; 134:1193-1196. https://doi. org/10.1043/2009-0417-oa.1. [PubMed]

61. Liao HF, Tai KY, Chen WS, Cheng LC, Ho HN, Lin SP. Functions of DNA methyltransferase 3-like in germ cells and beyond. Biol Cell. 2012; 104:571-587. https://doi. org/10.1111/boc.201100109. [PubMed]

62. Bergamaschi A, Tagliabue E, Sørlie T, Naume B, Triulzi T, Orlandi R, Russnes HG, Nesland JM, Tammi R, Auvinen P, Kosma VM, Ménard S, Børresen-Dale AL. Extracellular matrix signature identifies breast cancer subgroups with different clinical outcome. J Pathol. 2008; 214:357-367. https://doi.org/10.1002/path.2278. [PubMed]

63. Zhu H, Zhang Y, Geng Y, Lu W, Yin J, Li Z, Huang L, Liu $\mathrm{H}, \mathrm{Xu}$ N. IGFBP2 promotes the EMT of colorectal cancer cells by regulating E-cadherin expression. Int J Clin Exp Pathol. 2019; 12:2559-2565. [PubMed]
64. Liu Y, Song C, Shen F, Zhang J, Song SW. IGFBP2 promotes immunosuppression associated with its mesenchymal induction and Fc $\gamma$ RIIB phosphorylation in glioblastoma. PLoS One. 2019; 14:e0222999. https://doi. org/10.1371/journal.pone.0222999. [PubMed]

65. Zhang L, Lian R, Zhao J, Feng X, Ye R, Pan L, Wu J, Li M, Huang Y, Cai J. IGFBP7 inhibits cell proliferation by suppressing AKT activity and cell cycle progression in thyroid carcinoma. Cell Biosci. 2019; 9:44. https://doi. org/10.1186/s13578-019-0310-2. [PubMed]

66. Yue C, Yang M, Tian Q, Mo F, Peng J, Ma Y, Huang Y, Wang D, Wang Y, Hu Z. IGFBP7 is associated to prognosis and could suppress cell survival in cholangiocarcinoma. Artif Cells Nanomed Biotechnol. 2018; 46:817-825. https:// doi.org/10.1080/21691401.2018.1470524. [PubMed]

67. Verhagen HJ, van Gils N, Martiañez T, van Rhenen A, Rutten A, Denkers F, de Leeuw DC, Smit MA, Tsui ML, de Vos Klootwijk LL, Menezes RX, Çil M, Roemer MG, et al. IGFBP7 induces differentiation and loss of survival of human acute myeloid leukemia stem cells without affecting normal hematopoiesis. Cell Rep. 2018; 25:3021-3035. https://doi.org/10.1016/j.celrep.2018.11.062. [PubMed]

68. Wong RC, Ibrahim A, Fong H, Thompson N, Lock LF, Donovan PJ. L1TD1 is a marker for undifferentiated human embryonic stem cells. PLoS One. 2011; 6:e19355. https:// doi.org/10.1371/journal.pone.0019355. [PubMed]

69. Närvä E, Rahkonen N, Emani MR, Lund R, Pursiheimo JP, Nästi J, Autio R, Rasool O, Denessiouk K, Lähdesmäki H, Rao A, Lahesmaa R. RNA-binding protein L1TD1 interacts with LIN28 via RNA and is required for human embryonic stem cell self-renewal and cancer cell proliferation. Stem Cells. 2012; 30:452-460. https://doi.org/10.1002/ $\underline{\text { stem.1013. [PubMed] }}$

70. Yuan G, Regel I, Lian F, Friedrich T, Hitkova I, Hofheinz RD, Ströbel P, Langer R, Keller G, Röcken W, Zimmermann W, Schmid RM, Ebert MP, Burgermeister E. WNT6 is a novel target gene of caveolin-1 promoting chemoresistance to epirubicin in human gastric cancer cells. Oncogene. 2013; 32:375-387. https://doi.org/10.1038/onc.2012.40. [PubMed]

71. Zhang L, Yuan G, Fang Y, Qiu M, Lin J, Sun J, Yang D. Increased WNT6 expression in tumor cells predicts unfavorable survival in esophageal squamous cell carcinoma patients. Int J Clin Exp Pathol. 2015; 8:11421-11427. [PubMed]

72. Gonçalves CS, Vieira de Castro J, Pojo M, Martins EP, Queirós S, Chautard E, Taipa R, Pires MM, Pinto AA, Pardal F, Custódia C, Faria CC, Clara C, et al. WNT6 is a novel oncogenic prognostic biomarker in human glioblastoma. Theranostics. 2018; 8:4805-4823. https://doi. org/10.7150/thno.25025. [PubMed]

73. Lin YC, Murayama Y, Hashimoto K, Nakamura Y, Lin CS, Yokoyama KK, Saito S. Role of tumor suppressor genes in the cancer-associated reprogramming of human induced pluripotent stem cells. Stem Cell Res Ther. 2014; 5:58. https://doi.org/10.1186/scrt447. [ [PubMed] 
74. Park JT, Chen X, Trope CG, Davidson B, Shih I, Wang TL. Notch3 overexpression is related to the recurrence of ovarian cancer and confers resistance to carboplatin. Am J Pathol. 2010; 177:1087-1094. https://doi.org/10.2353/ ajpath.2010.100316. [PubMed]

75. Hu Y, Xiao Q, Chen H, He J, Tan Y, Liu Y, Wang Z, Yang Q, Shen X, Huang Y, Yuan Y, Ding K. BEX2 promotes tumor proliferation in colorectal cancer. Int J Biol Sci. 2017; 13:286-294. https://doi.org/10.7150/ijbs.15171. [PubMed]

76. Zhou X, Meng Q, Xu X, Zhi T, Shi Q, Wang Y, Yu R. Bex2 regulates cell proliferation and apoptosis in malignant glioma cells via the c-Jun NH2-terminal kinase pathway. Biochem Biophys Res Commun. 2012; 427:574-580. https://doi.org/10.1016/j.bbrc.2012.09.100. [PubMed]

77. Zhou X, Xu X, Meng Q, Hu J, Zhi T, Shi Q, Yu R. Bex2 is critical for migration and invasion in malignant glioma cells. J Mol Neurosci. 2013; 50:78-87. https://doi. org/10.1007/s12031-012-9864-8. [PubMed]

78. Agadzhanyan ZS, Doroshchuk AD, Shiryaeva YK, Dmitriev LF. Role of cytochrome b5 and alpha-tocopherol to microsomal and mitochondrial oxidation. Bull Exp Biol Med. 2013; 156:191-195. https://doi.org/10.1007/s10517013-2308-9. [PubMed]

79. Xiao X, Zhao W, Tian F, Zhou X, Zhang J, Huang T, Hou B, Du C, Wang S, Mo Y, Yu N, Zhou S, You J, et al. Cytochrome b5 reductase 2 is a novel candidate tumor suppressor gene frequently inactivated by promoter hypermethylation in human nasopharyngeal carcinoma. Tumour Biol. 2014; 35:3755-3763. https://doi.org/10.1007/ s13277-013-1497-1. [PubMed]

80. Habel N, Stefanovska B, Carene D, Patino-Garcia A, Lecanda F, Fromigue O. CYR61 triggers osteosarcoma metastatic spreading via an IGF1Rbeta-dependent EMT-like process. BMC Cancer. 2019; 19:62. https://doi.org/10.1186/ s12885-019-5282-4. [PubMed]

81. Xie L, Song X, Lin H, Chen Z, Li Q, Guo T, Xu T, Su T, Xu M, Chang X, Wang LK, Liang B, Huang D. Aberrant activation of CYR61 enhancers in colorectal cancer development. J Exp Clin Cancer Res. 2019; 38:213. https:// doi.org/10.1186/s13046-019-1217-9. [PubMed]

82. Vriens K, Christen S, Parik S, Broekaert D, Yoshinaga K, Talebi A, Dehairs J, Escalona-Noguero C, Schmieder R, Cornfield T, Charlton C, Romero-Pérez L, Rossi M, et al. Evidence for an alternative fatty acid desaturation pathway increasing cancer plasticity. Nature. 2019; 566:403-406. https://doi.org/10.1038/s41586-019-0904-1. [PubMed]

83. Liu Y, Pandey PR, Sharma S, Xing F, Wu K, Chittiboyina A, Wu SY, Tyagi A, Watabe K. ID2 and GJB2 promote early-stage breast cancer progression by regulating cancer stemness. Breast Cancer Res Treat. 2019; 175:77-90. https://doi.org/10.1007/s10549-018-05126-3. [PubMed]

84. Zhang Z, Rahme GJ, Chatterjee PD, Havrda MC, Israel MA. ID2 promotes survival of glioblastoma cells during metabolic stress by regulating mitochondrial function.
Cell Death Dis. 2017; 8:e2615. https://doi.org/10.1038/ cddis.2017.14. [PubMed]

85. Sumida T, Ishikawa A, Nakano H, Yamada T, Mori Y, Desprez PY. Targeting ID2 expression triggers a more differentiated phenotype and reduces aggressiveness in human salivary gland cancer cells. Genes Cells. 2016; 21:915-20. https://doi.org/10.1111/gtc.12389. [PubMed]

86. Lin SL, Wu SM, Chung IH, Lin YH, Chen CY, Chi HC, Lin TK, Yeh CT, Lin KH. Stimulation of interferon-stimulated gene 20 by thyroid hormone enhances angiogenesis in liver cancer. Neoplasia. 2018; 20:57-68. https://doi. org/10.1016/j.neo.2017.10.007. [PubMed]

87. Hamada T, Souda M, Yoshimura T, Sasaguri S, Hatanaka K, Tasaki T, Yoshioka T, Ohi Y, Yamada S, Tsutsui M, Umekita Y, Tanimoto A. Anti-apoptotic effects of PCP4/ PEP19 in human breast cancer cell lines: a novel oncotarget. Oncotarget. 2014; 5:6076-6086. https://doi.org/10.18632/ oncotarget.2161. [PubMed]

88. Liu D, Shen X, Zhu G, Xing M. REC8 is a novel tumor suppressor gene epigenetically robustly targeted by the PI3K pathway in thyroid cancer. Oncotarget. 2015; 6:39211-39224. https://doi.org/10.18632/oncotarget.5391. [PubMed]

89. Wu J, Bao L, Zhang Z, Yi X. Nrf2 induces cisplatin resistance via suppressing the iron export related gene SLC40A1 in ovarian cancer cells. Oncotarget. 2017; 8:93502-93515. https://doi.org/10.18632/oncotarget.19548. [PubMed]

90. Safaei R, Holzer AK, Katano K, Samimi G, Howell SB. The role of copper transporters in the development of resistance to Pt drugs. J Inorg Biochem. 2004; 98:1607-1613. https:// doi.org/10.1016/j.jinorgbio.2004.05.006. [PubMed]

91. Chu Y, You M, Zhang J, Gao G, Han R, Luo W, Liu T, Zuo J, Wang F. Adipose-derived mesenchymal stem cells enhance ovarian cancer growth and metastasis by increasing thymosin beta 4X-linked expression. Stem Cells Int. 2019; 2019:9037197. https://doi.org/10.1155/2019/9037197. [PubMed]

92. Chi LH, Chang WM, Chang YC, Chan YC, Tai CC, Leung KW, Chen CL, Wu ATH, Lai TC, Li YJ, Hsiao M. Global proteomics-based identification and validation of thymosin beta-4 X-linked as a prognostic marker for head and neck squamous cell carcinoma. Sci Rep. 2017; 7:9031. https:// doi.org/10.1038/s41598-017-09539-w. [PubMed]

93. Yu XJ, Song TJ, Zhang LW, Su Y, Wang KY, Sun Q. TRB3 is elevated in psoriasis vulgaris lesions and mediates $\mathrm{HaCaT}$ cells proliferation in vitro. J Investig Med. 2017; 65:10841088. https://doi.org/10.1136/jim-2017-000453. [PubMed]

94. Zhang X, Zhong N, Li X, Chen MB. TRIB3 promotes lung cancer progression by activating beta-catenin signaling. Eur J Pharmacol. 2019; 863:172697. https://doi.org/10.1016/j. ejphar.2019.172697. [PubMed]

95. Yu JM, Sun W, Wang ZH, Liang X, Hua F, Li K, Lv XX, Zhang XW, Liu YY, Yu JJ, Liu SS, Shang S, Wang F, et 
al. TRIB3 supports breast cancer stemness by suppressing FOXO1 degradation and enhancing SOX2 transcription.

Nat Commun. 2019; 10:5720. https://doi.org/10.1038/ s41467-019-13700-6. [PubMed]

96. Lobo J, Guimarães-Teixeira C, Barros-Silva D, MirandaGonçalves V, Camilo V, Guimarães R, Cantante M, Braga I, Maurício J, Oing C, Honecker F, Nettersheim D, Looijenga LHJ, et al. Efficacy of HDAC inhibitors belinostat and panobinostat against cisplatin-sensitive and cisplatinresistant testicular germ cell tumors. Cancers (Basel). 2020; 12:2903. https://doi.org/10.3390/cancers12102903. [PubMed]

97. Skowron MA, Vermeulen M, Winkelhausen A, Becker TK, Bremmer F, Petzsch P, Schönberger S, Calaminus G, Köhrer K, Albers P, Nettersheim D. CDK4/6 inhibition presents as a therapeutic option for paediatric and adult germ cell tumours and induces cell cycle arrest and apoptosis via canonical and non-canonical mechanisms. Br J Cancer. 2020; 123:378-391. https://doi.org/10.1038/s41416-0200891-x. [PubMed]
98. Schmidtova S, Dorssers LCJ, Kalavska K, Gillis AJM, Oosterhuis JW, Stoop H, Miklikova S, Kozovska Z, Burikova M, Gercakova K, Durinikova E, Chovanec M, Mego M, et al. Napabucasin overcomes cisplatin resistance in ovarian germ cell tumor-derived cell line by inhibiting cancer stemness. Cancer Cell Int. 2020; 20:364. https://doi. org/10.1186/s12935-020-01458-7. [PubMed]

99. Szklarczyk D, Gable AL, Lyon D, Junge A, Wyder S, Huerta-Cepas J, Simonovic M, Doncheva NT, Morris JH, Bork P, Jensen LJ, Mering CV. STRING v11: proteinprotein association networks with increased coverage, supporting functional discovery in genome-wide experimental datasets. Nucleic Acids Res. 2019; 47:D607D613. https://doi.org/10.1093/nar/gky1131. [PubMed] 